\title{
Services-Led Industrialization in India: Assessment and Lessons*
}

\author{
November 2006 \\ Nirvikar Singh \\ Department of Economics \\ and \\ Santa Cruz Center for International Economics \\ University of California, Santa Cruz
}

\begin{abstract}
This paper provides an integrated analysis of the role of the service sector in recent Indian economic development. It discusses the nature of services, their distinction from products, and their categorization. It provides an overview of India's overall growth experience, and a detailed examination of the contribution of the service sector to growth. It includes an examination of the potential for spillovers from IT, ITES and other service sectors such as financial services, to the rest of the economy, drawing on econometric work, as well as input-output analysis of linkages to understand these possible spillovers and growth potentials. Based on this evidence, it appears that India's manufacturing sector development may have been constrained in part by weaknesses in key service sectors such as transportation and electricity. The paper also considers the particular role of international trade in services, which is of growing importance. It discusses the consequences for employment of different growth paths, the challenges of education and manpower training to support and sustain India's development path, and social and environmental issues, including regional inequality issues. The Indian experience is related to recent discussions of industrial policy, and development policy more generally.
\end{abstract}

\footnotetext{
* This paper has been written for a project on Industrial Development for the 21 st Century, sponsored by UNDESA. I am grateful to David O'Connor and Monica Kjollerstrom for very perceptive and detailed comments. I also greatly benefited from comments on an earlier draft from T.N. Srinivasan, and from comments on my presentation by Dilek Aykut and participants in a project workshop at UNDESA. I am grateful to Shubhashis Gangopadhyay for providing me with more recent input-output data, Sanjay Hansda for his advice on the data, and Mukul Majumdar and Ilaria Osella for guidance on calculating leading sectors. Todd Feldman provided outstanding research assistance. Remaining errors are my responsibility. The views expressed here do not reflect those of the UNDESA or affiliated organizations.
} 


\title{
Services-Led Industrialization in India: Assessment and Lessons
}

\author{
November 2006 \\ Nirvikar Singh \\ Department of Economics \\ and \\ Santa Cruz Center for International Economics \\ University of California, Santa Cruz
}

\section{Introduction}

India has become one of the fastest growing economies in the world over the last two decades, arguably aided in this performance by economic reforms. One of the striking aspects of India's recent growth has been the dynamism of the service sector, particularly information technology (IT) and IT enabled services, while, in contrast, manufacturing has been less robust. The contribution of the service sector was particularly striking in the 1990s, which not only saw rapid growth (averaging over 6 percent since 1992), but also a higher contribution - over 60 percent (Hansda, 2001) - from services. This growth trajectory, which has been termed "services-led" industrialization, or even a "services revolution" (Gordon and Gupta, 2004) seems to stand out from the previous experience of economic development, which followed the traditional path from agriculture to manufacturing, with services becoming important at a later stage. In India, in contrast, there was a sharp increase in the share of services in GDP, from $37 \%$ in 1980 to $49 \%$ in $2002,{ }^{1}$ while the share of manufacturing remained about the same, at $16 \%$ (Kochhar et al, 2006). Thus questions arise about India's development pattern, including its nature, sustainability and replicability. This paper, therefore, reviews the recent growth

\footnotetext{
${ }^{1}$ As observed by authors such as Hansda (2002) and Gordon and Gupta (2004), most of this increase in the service sector's share of GDP came in the 1990s, not the 1980s. In keeping with this, the service sector's contribution to GDP growth was highest for the decade of the 1990s.
} 
experience of India, identifies the major contributing factors to its pattern of development, and examines the prospects for further "services-led" industrialization in India. The analysis will draw on theoretical models as well as case studies of the Indian experience.

The structure of the paper is as follows. The next section provides a conceptual framework for the examination of the Indian experience. In particular, we discuss the nature of services, their distinction from products, and their categorization. We argue that the precise nature of the services being considered is important for any analysis of growth impacts, and that one therefore has to go beyond broad national income accounts categories to understand the role of services in industrialization. Section 3 provides a brief overview of India's overall growth experience, followed by a more detailed examination of the contribution of the service sector to growth, and the relative performance of manufacturing and agriculture in Section 4. Section 5 examines the potential for spillovers from IT, ITES and other service sectors such as financial services, to the rest of the economy. We draw on econometric work on productivity growth, as well as input-output analysis of linkages to understand these possible spillovers. It is possible, based on this evidence, to hypothesize that India's manufacturing sector development may have been constrained, at least in part, by weaknesses in key service sectors such as transportation and electricity. In fact, other evidence suggests that telecommunications reforms were also critical for the rapid growth in IT and ITES. ${ }^{2}$

\footnotetext{
${ }^{2}$ I am grateful to David O'Connor for emphasizing these points to me.
} 
In Section 6, we consider the particular role of international trade in services. This deserves special treatment because of its growing importance, and because balance of payments constraints have often been major barriers to stable growth for developing countries. In Section 7 we discuss the consequences for employment of different growth paths, and the challenges of education and manpower training to support and sustain India's development path. Section 8 briefly considers the social and environmental issues associated with "services-led" or alternative development paths. The focus in this section is on regional inequality issues, as well as impacts that do not necessarily manifest themselves in the national income accounts and growth statistics. Section 9 relates the Indian experience as analyzed in this paper to some of the recent discussions of industrial policy, and development policy more generally. Section 10 offers a summary conclusion of the paper's findings.

\section{Conceptual Framework}

Much of the literature on service-led growth begins with broad national income accounting categories. However, it is important both to disaggregate services to identify important differences within that category, and stepping back from the accounting, to understand the key ways in which services differ from products, which themselves are classified as outputs of the manufacturing sector. A good starting point for analysis is a consideration of the precise nature of services vis-à-vis other kinds of productive activities. The differences will be seen to depend on the nature of market transactions as 
well as intrinsic characteristics of services vs. products, and both are subject to change as economies and technologies evolve.

The classical writers, such as Adam Smith and, earlier, the Physiocrats discussed services from the perspective of a distinction between productive and unproductive labor. Smith's idea of "unproductive labor" included the servants of wealthy individuals and government employees, as well as the military, the clergy, lawyers, doctors, writers and musicians, all of which are now included in the service sector. ${ }^{3}$ Of course, modern economics, based on utility and demand theory, has jettisoned this view, and services, however defined, are counted as productive activities. Various modern conceptual discussions of the distinct nature of services make similar observations. Hill (1977), for example, emphasizes the non-storability of services, which requires that services must be consumed as they are produced. Griliches (1992) defines services as anything that is the result of labor that does not produce a tangible commodity. Lack of tangibility is fundamentally what leads to non-storability, and to non-transferability (Economic Council of Canada, 1991). However, intangibility must, in the digital age, be carefully interpreted. Thus, software programs and various forms of digital electronic content have only limited tangibility, but are storable and transferable. The creation of these digital products may often be classified as a service, as also their delivery.

\footnotetext{
${ }^{3}$ Ricardo, Malthus, James Mill, and others shared this perspective, as did Marx, whose views influenced the national accounting systems of communist countries, where services were not counted in national output and as a result service industries were neglected. See Delaunay and Gadrey (1991) for a detailed historical account. Hansda (2001) also provides a survey of some of the literature on the role of services in an economy.
} 
The marketing literature pays considerable attention to the nature of services, and in this literature, the dimensions that distinguish services from products are summarized as follows: (1) intangibility, (2) heterogeneity, (3) simultaneity of production and consumption, and (4) perishability (e.g., Parasuraman, Zeithani and Berry, 1985; Rust and Chung, 2005). ${ }^{4}$ Several more fundamental economic implications are drawn from these distinguishing characteristics. For example, in this schema, intangibility, perishability and simultaneity all work against maintaining inventories. Heterogeneity and simultaneity (where the consumer is involved in creating the service) makes it more difficult to achieve scale economies. All of these features make display and consumer assessment of characteristics harder to achieve.

Of course, the use of the above four characteristics to distinguish services from products is subject to several caveats. First, the differences are mostly of degree, especially in comparing services to certain kinds of products. ${ }^{5}$ Second, and more fundamentally, the distinction between products and services is often based on the contractual nature of the market transaction. At the most fundamental level, every product either provides services directly, or is combined with other products to generate services. Thus, an automobile is purchased as a product, but its value is based on the stream of services that it will provide over time. All such durable goods may be leased or rented, in which case the service is more explicitly contracted for than in the case of a product transaction. The more

\footnotetext{
${ }^{4}$ These two references are merely illustrative of a significant literature in the field of marketing, which focuses on how firms' strategies must be tailored to deal with services as opposed to product marketing, including in particular the issue of managing service quality and customer relationships. Rust and Chung (2005) surveys this literature, the concerns of which are quite distinct from the focus in this chapter.

${ }^{5}$ In the marketing literature, Lovelock and Gummeson (2004) and Vargo and Lusch (2004) have recently challenged this framework, but from a particular, pragmatic perspective, arguing that these differences of degree have shrunk over time, for many kinds of services. This point can be made more generally, and we shall develop it further in this chapter.
} 
expensive the product (e.g., an airplane vs. an automobile), the less possible or economically desirable it is for an individual to access the services through a purchase. In fact, contracting for services from specialist providers is often a way to achieve economies of scale in providing services (or in making the underlying products) that would not be possible otherwise. The general point is that the boundary between products and services is often a function of market and economic conditions, rather than the intrinsic characteristics of what is being exchanged.

Previous analysts of this issue do recognize that the practical application of these conceptual distinctions in classifying services incorporates the contractual nature of the transaction. For example, in the case of utilities, Melvin (1995) points out that they are typically classified as services in the national income accounts, although gas, electricity and water are tangible goods. In these cases, the distribution systems are a critical aspect of enabling consumption of these goods, and the contractual relationship is primarily for delivery services using the distribution systems.

One exception to this blurring of the boundary between products and services is the case of personal services. To take a simple example, a practitioner of traditional Indian medicine (Ayurveda) may make a diagnosis based only on an examination of the patient, consisting of visual inspection and pulse reading, without any tools whatsoever. No product is involved in this service provision. Such pure personal services, without the use of any capital or tools, are increasingly rare: a modern doctor's services typically incorporate the use of large quantities of expensive equipment. Other personal services, 
such as those of lawyers and accountants, also involve the use of physical capital in their delivery, just as is the case for the examples of transportation services discussed in the previous paragraph. One idea that we develop in this section is the increasingly "industrial" or "manufacturing-like" character of such personal services. It is also worth noting that knowledge services, which have traditionally been personal services, are becoming more "industrialized" through the use of information technology: we also develop this point further in this section. By these characterizations, we mean the development of standardization, routinization, scalability and replicability for these services.

Besides the marketing literature, one area where the conceptual distinction between products and services has been explored in detail is that of international trade, where the categorizations are important for shaping international trade policies and agreements. Locational characteristics are central to discussions of services in international trade. For example, Bhagwati (1984) argues that services can be divided into two classes: those that require physical proximity of the user and provider; and those that do not. Services that require physical proximity can be further divided into three groups:

a) Mobile provider and immobile user, e.g., transporting labor to a construction site;

b) Mobile user and immobile provider, e.g., a patient going to a hospital;

c) Mobile user and mobile provider, e.g., students and professors meeting in a university for lectures.

A variation on the above classification is the basis for the World Trade Organization's (WTO's) categorization of services trade, which categorizes different "modes of supply" 
(Sampson and Snape, 1985; and Sapir and Winter, 1994 - see section 6 of this chapter for details). Finally, note that international trade in services can require the movement of factors of production (as in the construction labor example), in contrast to trade in goods, which normally substitutes for international factor movements.

Digital technology has also reduced the need for contact or physical proximity in many cases - these changes are at the heart of the new tradability of various knowledge-based services. Bhagwati (1985) was an early observer of the trend toward removal of proximity requirements through technological change, i.e., the increased richness and lower cost of long-distance communications. Melvin $(1989,1990)$ also explores this trend, characterizing services either as activities that require the double coincidence of time and location, or as activities that overcome constraints of time (e.g., storage services) and location (e.g., transportation services). He describes knowledge or information services as also overcoming a constraint - that of ignorance. Digital communications technology is, of course, behind the new wave of international trade in information or knowledge services.

[Table 1 about here]

In the international trade context, the skill-content of services as a distinguishing feature (Delaunay and Gadrey, 1991; Economic Council of Canada, 1991; Melvin, 1990) can also be important. Some kinds of low-skill services are susceptible to routinization and automation, whereas others are not (Dossani and Kenney, 2004). The former are 
therefore easier to trade. In some cases, service activities can be unbundled or "splintered" (Bhagwati, 1984) to allow the offshore outsourcing of the lower skill components (e.g., software testing in the overall process of software development). ${ }^{6}$ One trend that also seems to be emerging, however, is trade in services with higher skill content, such as financial analysis or patent preparation.

After one has clarified some of the conceptual characteristics of services, and their distinction from products, it is important to consider how measurement and classification are done in practice: "rather than discussing definitions, it may be more useful to take an operational approach and to examine what are actually called services in the national accounts and related statistical sources" (Griliches, 1992, p. 6). The Central Statistical Office in India provides a standard breakdown of services into 15 sub-sectors for that country (Gordon and Gupta, 2004), as shown in Table $1 .^{7}$ Note that this Indian classification does not include utilities, which are often classified as services elsewhere, because of the importance of distribution for electricity, gas and water. The salient point is the heterogeneity of the activities that are classified as services, in terms of capital intensity, skill-content, need for physical contact, and importance of tangible products as part of the service.

\footnotetext{
${ }^{6}$ Splintering therefore means separating service activities into components that can then be performed by different organizations, i.e., outsourced. Other examples, in addition to the software testing component of software development, are medical transcription and basic reading of x-rays as components of healthcare, checking for routine arithmetic or other errors as part of tax preparation services, and basic financial calculations as part of investment advice services. Outsourcing may allow economies of scale and specialization to be reaped, and may also permit the use of lower cost locations, as in offshoring. ${ }^{7}$ This categorization is slightly different from that used in the United Nations' International Standard Industrial Classification (ISIC): see Banga (2005).
} 


\section{India's Growth Experience: Overview}

Since our interest is in the role of services in India's recent growth, it is useful to have some perspective on the nature and extent of that growth. As we noted in the introduction, India's growth in the 1980s sped up from a moderate or slow rate prior to that decade, to a rate that doubled per capita growth, and ranked among the highest in the world over this period. There are numerous detailed reviews of India's growth experience in the last couple of decades, and we shall be selective and relatively brief. These reviews often discuss causal factors, albeit typically without formal econometric modeling, with the importance of economic reforms in the growth acceleration being the subject of some controversy. In other cases, econometric techniques have been used to identify structural breaks in the growth process, but without any causal modeling (e.g., Wallack, 2003). In this section, in addition to discussing aggregate growth performance, we also examine studies that focus on the performance of the service sector.

Panagariya (2005) provides a very careful appraisal of India's growth experience in the 1980s and 1990s, and of the 'revisionist' view, articulated by deLong (2003), Rodrik (2003) and Rodrik and Subramanian (2004a), that economic policy reforms in the 1990s were not key to India's growth performance in that decade. Those authors further argue that India's growth surge is properly understood as beginning in the 1980s, before the 1991 and subsequent economic reforms. Based on a careful examination of the data, Panagariya reaches three conclusions about India's growth experience in the last 25 years: 
1. Growth during the 1980 s was inconsistent, with the last three years of that decade contributing 7.6 percent annual growth, without which growth in the 1980s was only marginally better than that of the previous three decades.

2. The high growth in the last three years of the 1980 s was preceded or accompanied by significant economic reform, including trade and industrial policy liberalization.

3. Growth in the 1980 s was fueled by expansionary policies that entailed accumulation of a large external debt and contributed to an economic crisis.

Panagariya's final conclusion from his review of policy changes and growth performance is that it was "the 1991 market reforms and subsequent liberalizing policy changes that helped sustain growth."

Ultimately, the positive impact of economic policy reforms seems to have been accepted, even in the revisionist view. For example, while Rodrik and Subramanian (2004b) based on their earlier analysis (2004a) - use a growth accounting methodology to evaluate and project India's growth performance which de-emphasizes economic liberalization policies, they do not dismiss such policies. They focus on "metainstitutions" such as democracy and the rule of law, as well as conventional economic inputs such as human and physical capital, and productivity growth. In emphasizing these fundamentals, ${ }^{8}$ they highlight the infrastructure and human capital built up under the pre-

\footnotetext{
${ }^{8}$ Based on this analysis, these authors suggest that sustained growth of $7 \%$ or more is feasible for India. Mukherji (2006), in a recent paper, suggests that $8 \%$ is feasible, but not $10 \%$, though there is no exact connection between his qualitative discussion and these quantitative projections. Kelkar (2004) and Shome (2006) both provide arguments that $10 \%$ growth is feasible with the right policies in place. In April 2006, the Prime Minister, Manmohan Singh, articulated this figure as a feasible target in a speech to an industry group. Evaluating the feasibility of such growth targets requires an understanding of the determinants of India's growth, and this chapter may have a contribution in that direction.
} 
liberalization policy regime. At another level, however, their assumptions about the impacts of policy are not that different from those of Panagariya, since they state, "policy liberalisation will progressively erode the licence-quota-permit raj as a source of corruption and patronage that has had such a corrosive effect on public institutions." In addition to this indirect effect, they also attribute productivity growth directly to reforms that removed the "shackles on the private sector." The case of IT illustrates the positive impact of the 1990s reforms, with telecommunications reform and liberalization leading the way for that sector. One of the best-known, most successful participants in this industry has documented the positive impact of liberalization, including general steps to ease the conduct of business (Murthy, 2004).

While Panagariya shows that average growth rates are very sensitive to how one divides the period under consideration, one might argue that the data itself should be allowed to reveal when a growth acceleration occurred for India, rather than being determined subjectively. Time series methods to test for structural breaks are designed to achieve this. Wallack's (2003) study is the most comprehensive along these lines, and examines time series data for 1951-2001. ${ }^{9}$ The tests are applied to aggregate GDP data as well as to sectoral data. The latter, in particular, is of interest for understanding the recent pattern of economic development in India. Since these are pure time series estimations, there are no structural explanatory variables, but one can plausibly compare the identified break dates with what we know independently about policy changes or other macroeconomic events.

\footnotetext{
${ }^{9}$ The methodology consists of taking all possible structural break dates, calculating each possible Fstatistic, and using the maximum of these statistics to choose an initial break date. This is termed the sup-F statistic. The process is repeated for subsamples on either side of the initially identified break to isolate additional break dates. See Wallack (2003) for details and references on the statistical methodology.
} 
[Table 2 about here]

The results are summarized in Table 2, and provide some plausible connections between growth and economic environment changes (such as low interest rates, an investment surge, or the IT boom). As Wallack herself emphasizes, the results are not as robust as one would like, since other years often have F-statistics close to the maximum values. ${ }^{10}$ However, there are two important conclusions. First, there is evidence for a break in the aggregate GDP growth rate in 1980 (and in 1987 for GNP). Second, there is little evidence that this was caused by a break in the growth of any sector - instead, as T.N. Srinivasan has emphasized, much of the growth rate change probably came from a shift in activity from slower-growing to faster growing sectors (Srinivasan, 2003). ${ }^{11}$ The results of the statistical tests suggest some exceptions to this observation (Table 2). One is the breaks in financial, real estate and business services in 1974 and 1980. Wallack suggests these were the result of low interest rates in 1974, and an investment boom beginning in $1980 .{ }^{12}$ There is also a break in trade, transport, storage and communication services in 1992: Wallack relates this to telecommunications reform and the growth of IT, but those factors may have come into play somewhat later. Clearly, this empirical approach needs to be explored further to understand the behavior of the Indian economy.

\footnotetext{
${ }^{10}$ This can be seen in the broad confidence intervals for the break years reported in Wallack (2003) - for example, that for GDP is 1973 to 1987, while for the trade, transport, storage and communication sector, it is 1988 to 1996.

${ }^{11}$ This point is recognized by Wallack, and also emerges from the analysis of Bosworth, Collins and Virmani (2007).

${ }^{12}$ She also finds weaker evidence for a break in 1993 for finance and related services. Gordon and Gupta (2004) suggest that there was a structural break in overall services sector growth in 1980 (their Figure 4), but the statistical methodology for this conclusion is not explained.
} 
In addition to the time series evidence for structural breaks in some service sectors, there are more general empirical observations on service sector growth in India (Hansda, 2002). For example, the share of services in gross capital formation declined from $57.7 \%$ in $1950-51$ to $48.8 \%$ a decade later, and further to $43.7 \%$ in $1970-71$. Thereafter, however, the share has not changed that much, hovering around $40 \%$. One can make conjectures about changes in capital and labor productivity in the service sector (Hansda, 2002), but since the composition of the sector has changed substantially over time, and these sectors have different capital intensities, it is difficult to reach any definite conclusion from the data as presented (Hansda, 2002, Tables 7 through 9). Hansda also suggests that the terms of trade moved against the service sector in the latter part of the 1990s, with finance, insurance, real estate and business services and trade, transport, storage, and communication together contributing to that decline. Liberalization, competition and technological progress may all have contributed to this development. ${ }^{13}$

A disaggregated view of service sector growth in India, using the CSO classification as described in Table 1 (Gordon and Gupta, 2004), gives a stronger indication of growth acceleration than the formal time series analysis. Gordon and Gupta note that 12 of 15 service sub-sectors in India grew faster than GDP over the 50 year period beginning in 1951, but the growth acceleration in the 1990s, which was responsible for India becoming an outlier in the service sector share (as compared to typical developing

\footnotetext{
${ }^{13}$ Hansda compares a services deflator with the GDP deflator. These observations on relative price trends are repeated and updated by Gordon and Gupta (2004, Figure 8). They analyze this as follows. If the growth in services output was largely a demand side phenomenon, there would not be this decline in the relative price of the fast-growing services. On the other hand, prices in sub-sectors that grew at trend rates rose faster than the GDP deflator, suggesting that a different mix of supply and demand factors were at work there. T.N. Srinivasan (personal communication) has suggested to me that the deflators used for these calculations are unreliable in their construction. That point is also raised in Bosworth, Collins and Virmani (2007).
} 
countries at that income level), was the strongest in business services, communication, and banking services, followed by hotels and restaurants and community services (Gordon and Gupta, Table 5). These five sub-sectors together accounted for the entire acceleration in services growth in the 1990s. They assert that growth in other sub-sectors in the 1990s was broadly similar to, or lower than, that in the previous decades. ${ }^{14}$ This pattern of growth is considered further in the Sections 4 and 5 of this chapter, in the context of service sector contributions and linkages in the economy.

Two other aspects of the performance of India's service sector are noteworthy. First, following an international trend, FDI inflows into India have moved increasingly away from manufacturing, and towards services sector, even as they have increased overall. These flows have been heavily concentrated in telecommunications and financial services (Banga, 2005, Figure 7). Second, the structure of indirect taxation in India, with historically light or zero taxation of services due to the nature of constitutional tax provision, has meant that the recent growth of the service sector has been associated with an overall tax-GDP ratio below the norm for countries at similar income levels. ${ }^{15}$ While services crossed $50 \%$ as a share of GDP in the 1990 s, they contributed only about $10 \%$ of total tax revenue (Hansda, 2002, Table 11). This situation is changing, with moves to change constitutional tax assignments and bring services broadly into the indirect tax base.

\footnotetext{
${ }^{14}$ In some cases, they appear to confuse statements about growth levels with growth differences. For example, banking services grew at $11.9 \%$ in the $1980 \mathrm{~s}$ and $12.7 \%$ in the $1990 \mathrm{~s}$, which is not much of an acceleration, but well above the total for the service sector (Gordon and Gupta, Table 1). On the other hand, personal services grew at $2.4 \%$ in the $1980 \mathrm{~s}$ and $5 \%$ in the $1990 \mathrm{~s}$, a greater acceleration, but below the overall service sector growth in each case.

${ }^{15}$ There have been conflicting analyses of India's tax-GDP ratio, but Rao (2005) seems to provide definite support for the assertion made here.
} 
In addition to analyses of aggregate and sectoral growth, summarized above, a recent review of India's pattern of development (Kochhar et al, 2006) focuses on skill-intensity, and suggests that the nature of the economic policies followed by India from independence onward created a pattern of specialization that was already somewhat distinct from the typical developing country at comparable income levels. This, in turn, shaped the country's development pattern in the post-1980 reform period. In particular, India's manufacturing sector was more diversified, more skill-intensive, and less (unskilled) labor-intensive than average. In fact, it is suggested that the data indicates that India's service sector was smaller than normal up to the early $1980 \mathrm{~s} .{ }^{16}$ Thus, while the last two decades have seen a continuation of unusually skill-intensive growth, the rapid growth since the 1980s in services (still chiefly skill-intensive, however) represents a departure from the past.

Kochhar et al examine the performance of the Indian economy in the 1980s and 1990s, starting from these apparently unusual 1980 preconditions. GDP per worker and total factor productivity (TFP) both grew more rapidly in these two decades, as compared to the 1970s. Cross-country level regressions for the year 2000 suggest that India's services share was significantly higher than the norm in that year (by 3.8 percentage points), but only when a country size variable was included. On the other hand, employment was always significantly lower than the norm, and by a large magnitude, of 17 percentage points. This result is consistent, then, with the kind of skill-biased development observed

\footnotetext{
${ }^{16}$ This conclusion is reached from a cross-country regression which controls for per capita GDP as well as land area. See Kochhar et al (2006), Table 2. The rationale for the size variable is not apparent.
} 
in India pre-1980. Regressions using the change in the share of services also indicated that India was a positive outlier during the period 1981-2000 (Kochhar et al, Table 5). According to this analysis, the 1980s and 1990s also saw an accentuation of the skill-bias in India's manufacturing, including whatever is measured of the informal sector. A conjecture is that incomplete labor market reforms and continued skewed education sector spending might be underlying factors behind the observed pattern of growth, in which case it might be altered by policy changes. On the other hand, hysteresis in development paths might accentuate the observed biases in the future. State-level sectoral growth data seems to support the latter possibility: states such as Tamil Nadu and Maharashtra, according to this analysis, appear to be behaving more like advanced skillintensive countries in their growth pattern.

The concerns raised by Kochhar et al about India's somewhat skewed pattern of development, and its implications for income and regional inequality, will be taken up in more detail in later sections, particularly in the context of employment, education and training (Section 7), social issues (Section 8), and broader lessons for development policy (Section 9). Here, we offer one word of caution on their analysis. Historical patterns of development and cross-country comparisons are an important component of empirical analysis. ${ }^{17}$ Nevertheless, these comparisons may miss certain kinds of innovations that are not captured in the data. In particular, the development of modern business process outsourcing represents a rather new form of organizing economic activity, and an opportunity at many skill levels, that may not have been possible in the past. This goes

\footnotetext{
${ }^{17}$ Gordon and Gupta (2004, Section 2) also provide a brief survey of some of this kind of evidence. Dasgupta and Singh (2005a, b) provide further cross-country regressions.
} 
back to our conceptual discussion in the previous section. To offer an imperfect analogy, Japan in 1950 was not viewed as a likely candidate for building a world class automobile industry. The industry was both capital intensive and technologically advanced. Nevertheless, Japan not only succeeded, but there were arguably positive spillovers from this effort to other engineering-intensive manufacturing. The imperfections in this analogy include substantial differences in initial conditions and social heterogeneity, but the caveat on extrapolating from the past should be kept in mind.

\section{Understanding Service Sector Growth and its Impacts}

The discussion in the last section has suggested that India's more rapid growth in the 1980s and, especially, the 1990s has been the result of policy changes as well as initial conditions. The pattern of growth has been skewed toward the service sector, as well as toward skill-intensive activities. As noted in the introduction, India's service sector was responsible for over $60 \%$ of its GDP growth in the 1990 s, well above the sector's contribution in previous decades. A small number of service sub-sectors seem to have led the overall contribution of services to GDP growth. In fact, the four fast growing subsectors in the 1990s accounted for effectively all of the more rapid services growth of the 1990s.

In this section, we begin with the empirical question of what factors can explain observed service sector and sub-sector growth in India. One possible answer is increased specialization, or splintering (Kravis et al, 1983; Bhagwati, 1984), which, if it occurs 
across sectors, would alter the aggregate accounting. More precisely, if services components of manufacturing activity such as accounting, research and development, or logistics are splintered off and outsourced to other firms, they will be accounted for as service sector contributions to GDP, rather than being subsumed in manufacturing value added. Using input-output coefficients constructed by Sastry et al (2003), Gordon and Gupta (2004) provide one possible estimate of this effect, based on changes in those coefficients. The input coefficients of services in agriculture and manufacturing increased enough in the 1980 s to add 0.5 percentage points to service sector growth in that decade. ${ }^{18}$ Using input-output coefficients constructed from 1998-99 data, we are able to repeat this calculation for the 1990s, obtaining essentially no contribution of splintering in the 1990 s, if measured in this manner. ${ }^{19}$ However, this data and methodology does not permit an analysis of the extent to which cross-country splintering, which became more important in the 1990s, e.g., through offshore outsourcing of business services, would explain the observed patterns of service sector growth. In the latter case, there is a real shift in economic activity to India, whereas domestic splintering is more of an accounting change. Even in the latter case, however, when specialization is associated with efficiency improvements, purely domestic splintering may reflect a positive economic change.

\footnotetext{
${ }^{18}$ The calculation is as follows. The input-output coefficients for services input in agriculture and industry increased by 0.03 and 0.04 , respectively, during the 1980s. These coefficient changes would have increased demand for services (as a first round effect) by $\Delta \mathrm{Y}_{\mathrm{S}}=0.03 \mathrm{Y}_{\mathrm{A}}+0.04 \mathrm{Y}_{\mathrm{I}}$, where $\mathrm{Y}_{\mathrm{i}}$ is the output in sector $\mathrm{i}$. Dividing through by total output $Y$ and evaluating at the average sectoral shares during the $1980 \mathrm{~s}(0.35$, 0.25 and 0.40 for agriculture, industry and services, respectively $)$, yields $\Delta \mathrm{Y}_{\mathrm{S}} / \mathrm{Y}_{\mathrm{S}}=((0.03 * 0.35)+$ $(0.04 * 0.25)) / 0.4=0.051$.

${ }^{19}$ The calculation is available from the author: see Table 3 for the data. Gordon and Gupta argue that since some of the fastest growing service sub-sectors in the 1990s were geared toward final consumption (e.g., community services, communication services, and hotels and restaurants), this would fit with splintering having been less important in boosting growth in the 1990s versus the 1980s. On the other hand, business and financial services growth was also important in the 1990s, consistent with splintering of these services out of manufacturing.
} 
Along with increased specialization, another basic reason for an increasing share of services in GDP as an economy grows is a higher than average income elasticity of demand. ${ }^{20}$ Thus, the share of services in private final consumption expenditure grew faster in the two decades beginning 1980 than did services as a share of GDP (Hansda, 2002, Table 5). Aside from a big jump in the share of the sub-category "operation of personal transport equipment" in the 1980s, the shares of different kinds of final consumption services were relatively stable in this period (Hansda, 2002, Table 6). Gordon and Gupta (2004, Table 8) estimate that final consumption of services grew at a similar rate to overall services in the 1990 s, but slower in the 1980 s, which would be consistent with our calculation (and their argument) that splintering through specialization was a less significant contributing factor to services growth in the latter decade. Finally, the accelerated growth in services in the 1990s, along with a decline in their relative prices $^{21}$ is not consistent with a purely demand driven explanation of services growth.

A third possible factor in explaining service sector performance in India is the role of policy liberalization. Based on an industry case study (Murthy, 2004), we have noted the importance of liberalization in general, and telecommunications reform in particular, as a factor in the growth of IT and ITES. Gordon and Gupta (2004) make essentially the same point using patterns in the data. In the absence of any good measure of liberalization, they

\footnotetext{
${ }^{20}$ This factor can apply to certain goods as well, especially consumer durables. The Japanese decision to pursue automobile production in the 1950s was apparently based on the high income elasticity of demand for automobiles.

${ }^{21}$ Recall Hansda's discussion of changes in the sectoral terms of trade, summarized in the previous section. Again, the data on sectoral price deflators must be applied with caution.
} 
note that the communications sub-sector grew rapidly in the 1990 s coincident with deregulation, that the private sector share in the service sector grew in this period, and that FDI was positively correlated with services growth. This period also saw a rapid increase in service sector exports, which may have been aided by domestic liberalization: the international aspects of India's service sector growth are taken up in Section 6.

Some further quantification of the contribution of the various factors affecting services growth (splintering, high income elasticity, exports and policy reforms) in the 1990s is provided by Gordon and Gupta through a basic growth accounting exercise. They first estimate a pre-1990 trend growth rate for service sub-sectors that accelerated in the 1990s, of about 1.5 percent. This is assigned to splintering and high income elasticity, as relatively constant factors. The residual is about 1.75 percentage points of service sector growth. Growth due to exports is estimated at about 0.5 percentage point. ${ }^{22}$ The remaining residual, of 1.25 percentage points, is assigned to policy liberalization and technological progress. These estimates are somewhat rough and ready, but can provide a basis for examining more detailed econometric work on the contributions of and to service sector growth. A set of sub-sector specific and pooled time series regressions to econometrically estimate the factors determining services growth are consistent with the conclusion a positive impact of reform on services growth (Gordon and Gupta, 2004,

\footnotetext{
${ }^{22}$ The immediate justification for this number is not provided, but appears to be based on the Sastry et al input-output matrix, with some assumptions about input usage for services exports relative to services overall.
} 
Tables 9 and 10). There also appears to be a positive impact of industrial growth on services growth, as one might expect. ${ }^{23}$

A complementary question to that of the impacts of industrial growth on services growth concerns the impact of services on manufacturing production and productivity (Banga and Goldar, 2004). These authors perform a sources-of-growth analysis, in which services are included as an input to manufacturing. ${ }^{24}$ They first use panel data for 148 three-digit level industries covering 18 years, 1980-81 to $1997-98$, to estimate a production function, and based on this econometric estimation, the sources of growth analysis is carried out. It is estimated that, although service inputs contributed little to the production of the registered manufacturing sector during the 1980s (only 1\% of output growth), the contribution of services increased substantially in the 1990s (to about $25 \%$ of output growth). This, in turn, implies that excluding services inputs overstates the extent of manufacturing TFP growth in the 1990s. In fact, when the authors regress their TFP index on a set of explanatory variables that includes the ratio of services input to employment, a statistically significant positive relationship is found between services input and industrial productivity, though the estimated elasticity is not large. These results suggest that the increasing use of services in manufacturing in the 1990s favorably

\footnotetext{
${ }^{23}$ The time series estimates use annual data from 1952 to 2000 . In sub-sector specific regressions, the dependent variable is the annual growth rate for that services sub-sector. The right hand side variables include the growth rates of the commodity producing sectors, the volume of the external trade of goods, and the value of exports in services, and dummies for the 1980s and 1990s. To smooth out noise in the annual data, the authors use three-year moving average growth rates. Alternative regressions with separate dummies for the two halves of the 1990s also fit with the observation that policy reform in services such as communications only took hold in the latter part of the decade. The pooled regressions are estimated for the period 1970-2000, with similar averaging and explanatory variables. The main difference in these regressions is that sub-sector specific dummies are used, measuring whether reforms were implemented in each sub-sector. These dummy variables turn out to be most significant.

${ }^{24}$ In the absence of direct data on services inputs at the disaggregate level used by the authors, they calculate services as a residual, i.e., the difference between total input costs and the cost of materials and energy.
} 
affected TFP. ${ }^{25}$ The results of this analysis also suggest that trade reforms played an important role in increasing the use of services in the manufacturing sector. It is not clear, however, to what extent this increased use reflects splintering, or other changes in the organization of manufacturing. ${ }^{26}$

Finally, Bosworth, Collins and Virmani (2007) examine the role of services as part of a detailed, up-to-date growth accounting for India. A major result is that TFP growth in the service sector has been very high (almost three percent per year) in recent decades, while the contribution of capital is relatively low. Since half this sector's growth has come in 'traditional' sub-sectors such as trade, transportation, and community and personal services, where great productivity improvements might not be expected, they argue that price increases in services may be underestimated, leading to an overestimate of real growth in this sector. If correct, this view has serious implications for overall Indian growth measures. However, an alternative explanation, discussed later in this section, may lie in reductions in transaction costs associated with policy reforms.

Combined, the empirical results summarized above suggest that services have not only played a positive, direct role in India's economic growth in the last decades, but may have also helped spur manufacturing growth. While the latter impact was not visible in aggregate data for the 1990s (barring a two year boom in 1994-96), more recent data

\footnotetext{
${ }^{25}$ A set of regressions by Dasgupta and Singh (2005b) using aggregate data is relevant in this context. Using cross-section data for 42 developing countries, they find that manufacturing and services have similar, strongly positive effects on TFP growth.

${ }^{26}$ I am grateful to David O'Connor for raising this issue. The impact of splintering on manufacturing productivity would depend on the relative productivity of ancillary service activities versus core manufacturing activities. If the service activities are both low productivity and more efficient when outsourced, there would be two sources of measured productivity gains in manufacturing.
} 
suggests stronger manufacturing growth (Ministry of Finance, 2006). Furthermore, since the growth of the services sector has been more robust than that of manufacturing, a relatively clear picture emerges of services driving the Indian growth process. There are serious concerns about skill-intensity and employment, which we consider in Section 7, but the central conceptual question from a growth perspective is whether the empirical experience can be related to an underlying theoretical understanding. The traditional development paradigm of "agriculture to manufacturing to services" (e.g., Kuznets, 1959; Kaldor, 1966; Pack and Westphal, 1986) not only makes manufacturing central to the transition to modernity, but also necessary for sustained productivity growth, since an increasingly important service sector is viewed as a symptom of a mature economy and slower growth (Baumol, 1967).

Therefore, in addition to the above empirical studies, we also consider the conceptual role of services, and information technology in particular, in reducing transaction costs and improving productivity in manufacturing. In fact, a recent major empirical study of the United States (Triplett and Bosworth, 2004) concludes that services sector productivity increases were responsible for the strong growth in the US in the latter half of the 1990s, with information and communication technologies (ICTs) playing a significant role in this productivity effect. One aspect of this impact is the possibility that technological change, including the use of ICTs in particular, has made some services more routinized, and therefore more like manufacturing. For example, a large-scale call center is run more like a factory, reaping economies of scale, rather than a traditional services organization, which would have traditionally provided customized or differentiated services at a 
relatively small scale. While there is some skepticism about the long-run impacts of ICTs (e.g., Joshi, 2004), there seems to be a well understood case for focusing on ICTs, providing both services and products, in the growth process. For example, Dasgupta and Singh (2005a, footnote 8) state that, "IT [information technology], however, produces both new products and processes. Nevertheless, from the Kaldorian perspective, what is important is whether IT, be it product, service or process, and manufacturing are subject to increasing or decreasing returns to scale, to dynamic economies of scale and to spill over effects for the rest of economy." While the macroeconomic data may not answer this question, microeconomic studies of developed countries directly establish the positive impacts of IT use on productivity (e.g., Bresnahan, Brynjolfsson and Hitt, 2002; OECD, 2004).

Another key aspect of ICTs' development impacts comes through reductions in transaction costs. This term can be interpreted broadly, to include various kinds of costs of communication, transportation, and other aspects of exchange, such as costs of searching for options, negotiating contracts and enforcing agreements. ${ }^{27}$ Singh (2004a) constructs an illustrative model to show precisely how transaction cost reductions can increase short run efficiency, as well as boost the long run steady state of the economy. The simplest and most basic aspect of transaction costs is that they result in resources used up in exchange, and drive a wedge between the supply price and the demand price in a competitive market. If transaction costs are high enough, the relevant market will not

\footnotetext{
${ }^{27}$ While Coase (1937) does not use the term, his 'marketing costs' are the essence of the modern concept. Williamson, for example $(1975,1981)$, extends the analysis of transaction costs to relationships within organizations, which allows us to interpret the work of Bresnahan et al (2002) and the studies in OECD (2004) in a transaction cost context.
} 
exist, in the sense that the quantity exchanged is zero. If the transaction cost consists purely of resources used up in the process of exchange, then the welfare loss from its existence consists of the usual Harberger deadweight loss triangle, plus the transaction cost rectangle, which can be substantially larger. If the transaction cost is actually a payment to an intermediary, or a tax imposed by the government, then the welfare loss is just the Harberger triangle. Romer (1994), in an influential paper, argues that even if the rectangles represent a redistribution, and not a resource cost, there is a welfare cost that goes well beyond the usual Harberger triangles. The basic idea is that if there is a fixed cost of producing a good, transaction costs can reduce operating profits to the extent that some goods are no longer produced, leading to a larger loss of welfare than would otherwise be the case.

From a development perspective, the main implication of domestic transaction costs, i.e., their effect on the equilibrium number of intermediate goods, and hence on output and welfare, must be sought in a dynamic model. Romer hints at this, but the first formal model is that of Singh (2004a), building on the analysis of Ciccone and Matsuyama (1996). This uses a dynamic monopolistic competition model, in which an economy that inherits a small range of differentiated intermediate inputs can be trapped into a lower stage of development. In particular, the model may have multiple steady state equilibria, and the starting point of the economy can determine which steady state is approached. Singh (2004a) shows that if transaction costs determine the initial number of varieties of the intermediate good, then reducing transaction costs can jump start the economy, moving it to a path that leads to a higher steady state. In addition, transaction costs will 
affect the long-run equilibrium number of varieties, and hence the level of the steady state. Transaction costs can reduce the long-run steady state level of the economy, and even arrest the process of development. ${ }^{28}$ The use of ICTs, by reducing transaction costs, can mitigate both these effects. ${ }^{29}$ Note that, although Singh (2004a) emphasizes ICTs, improved transportation and distribution can also bring down transaction costs. The connection to the empirical work on the growth of the Indian service sector reviewed earlier in this section should be clear: the fast growing services have included some subsectors that are critical determinants of major aspects of transaction costs for the Indian economy. From this perspective, one might also view infrastructure constraints in transportation as one manifestation of high transaction costs. ${ }^{30}$

In addition to affecting transaction costs, certain kinds of services may impact the rate of innovation, so that their growth is critical in determining development. The obvious perspective to take in this case is that of the endogenous growth literature, which emphasizes the role of innovation (e.g., Grossman and Helpman, 1991; Romer, 1990). In this context, the critical aspect of services growth is their knowledge intensity. The comprehensive study of Dahlman and Utz (2005) analyzes the development of a "knowledge economy" in India. These authors emphasize R\&D quite broadly, and range over issues of governance institutions and education, as well as the national system of innovation. Implicitly their treatment of education partially deals with the concerns about

\footnotetext{
${ }^{28}$ The economic intuition is that, as intermediate goods producers must increase their prices to compensate for transaction costs, the substitutability of undifferentiated labor for their inputs reduces their share of final value, and forces marginal intermediate goods out of production.

${ }^{29}$ Singh $(2004 b, 2005)$ consider how these impacts can be realized in practice in rural areas, using case studies and examples from fieldwork in rural India.

${ }^{30}$ See also Gulyani (2001) for an empirical analysis of transportation costs and their impacts on the Indian automobile industry. I am grateful to David O'Connor for the point made in the text, and this reference.
} 
skill intensity expressed by Kochhar et al (2006), by highlighting the importance of skilled labor in development: we postpone details until Section 7. Their perspective converges with the transaction cost approach in emphasizing the need to improve the ICT infrastructure, which will in turn speed and enhance the acquisition, creation, dissemination, and use of knowledge.

Singh (2003) provides a formal analysis of how improving ICTs can enhance growth. His growth model to capture the special role of ICTs in economic growth, as an enabler of efficient communication and storage of information, is an extension of the recombinant growth model of Weitzman (1998). The central idea of this approach is that new ideas are formed through combinations of old ideas. A key property of this formulation is that the increase in the number of ideas is faster than geometric growth (Weitzman, 1998, Lemma, p. 338). The rate at which potential ideas are converted into new ones depends on a "success rate", which is a function of the current level of resources spent per potential new idea, i.e., the level of R\&D. In Weitzman's model, all ideas are the same, and the actual number of new ideas is given by the number of potential new ideas multiplied by the success rate. Singh (2003) modifies Weitzman's model to allow the stock of ICT knowledge to independently affect this success rate, so that ICT gives the growth process an extra 'kick,' beyond that which comes from recombinant growth in general. $^{31}$

\footnotetext{
${ }^{31}$ One might argue that other technologies can have similar effects, in supporting innovation. Nevertheless, it seems that the specialness of IT is precisely that it facilitates innovation: without writing, without telephones, without the Internet, the success rate of converting potential new ideas into actual additions to the stock of knowledge would be lower.
} 


\section{Linkages and Spillovers}

The analysis of the previous section can be extended and complemented by explicitly considering linkages in an input-output framework. The goal is to quantify the extent to which services, manufacturing and agriculture have spillover effects on each other. A single year's input-output data provides this information in a static context, whereas examining changes in coefficients over time can provide some insight into structural changes in the economy. For example, Sastry et al (2003) $)^{32}$ construct input coefficient matrices for four years: 1968-69, 1979-80, 1989-90 and 1993-94 (see Table 3). The basic observation is that over this period, agricultural production became more industry and services intensive, whereas industrial production became less agriculture intensive and more services intensive. For the production of services, the main change was greater service intensity. Some of these changes took place more uniformly through this time period, but the greatest changes in the Indian economy's production structure, by this measure, came in the 1980s and 1990s. As Table 3 shows, our own calculations for 199899 suggest little change in this respect. These observations are, of course, consistent with the analyses presented earlier. ${ }^{33}$

\footnotetext{
${ }^{32}$ As noted earlier, their calculations are used by Gordon and Gupta (2004) in the latter's informal growth accounting exercise. The Sastry et al approach to linkages draws on earlier work of Ahluwalia and Rangarajan (1986)

${ }^{33}$ An alternative to the production linkages in Table 3 uses the Leontief inverse to calculate what can be termed demand linkages (Sastry et al, 2002, Table 4). While statements about production intensity are based on the direct input-output coefficients, summarized in a "Leontief" matrix A, the matrix $(\mathbf{I}-\mathbf{A})^{-1}$ (the Leontief inverse), represents the direct and indirect requirements of gross output in all activities needed to support one unit of final demand in each activity: these requirements are the basis for considering demand linkages. As one would expect, agriculture became more connected to industry and services, in terms of demand for the outputs of those sectors. Sastry et al calculate that during 1968-69, a rise in agricultural output by one unit would have raised demand for industrial goods by 0.087 units, and demand for services by 0.035 units. In 1993-94, on the other hand, one unit of increase in the agricultural output would have raised the demand for industrial goods by 0.297 units, with this sharp increase having occurred largely in the 1980s. Conversely, and as expected, demand linkages of industry weakened with respect to agriculture
} 
[Table 4 about here]

The input-output approach is applied at a much more disaggregated level by Hansda (2001). His goal is to address the larger question of the sustainability of services-led growth for the Indian economy. He uses input-output transactions tables for 1993-94, disaggregated at the level of 115 activities (22 in agriculture, 80 in industry, and 13 in services), as well as at the level of 10 broad sectors. At these disaggregated levels, Hansda's analysis suggests that the Indian economy is quite services-intensive with industry being the most services-intensive sector. Table 4 (adapted from Hansda, 2001, Table 5, and partially updated to 1998-99), summarizes the pattern of above average intensity for sectors falling into the three overall categories of agriculture, industry and services. The main conclusion, on the services intensity of industrial activities, is validated by the bold numbers in Table 4, indicating a large fraction of industrial activities with above-average services intensity. This conclusion is in line with the Sastry et al aggregated data for 1993-94, and our calculations for 1998-99 (Table 3).

One can also examine the data at an intermediate level of aggregation, as in Table 5 (adapted from Hansda, 2001, Table 6 and partially updated). The numbers here are the direct (for 1993-94 and 1998-99) and indirect (for 1993-94) sectoral intensities,

(again, largely in the 1980s). However, they increased by $50 \%$ in the 1980 s with respect to services, with a further increase by 1993-94. Demand linkages of the services sector remained almost constant in the case of agriculture over the whole time period, whereas there was an increase in the demand linkages with industry, again mostly in the 1980s. The overall story of the changes in demand linkages is thus consistent with that of production linkages. 
corresponding to the numbers reported by Sastry et al, but at a level of disaggregation that allows a greater understanding of the pattern of linkages of the different services subsectors. Note that the columns are further aggregated at the level of the three sectors agriculture, industry and services. The different aggregation gives intensities somewhat at variance with the Sastry et al calculations, but the conclusion of the importance of services still emerges clearly. Manufacturing, construction and "electricity, gas and water supply" are all services intensive. On the other hand, among services activities, "transport, storage and communication" are together quite industry intensive, while "personal, social and other services," and "trade, hotels and restaurants" are also somewhat industry intensive. As one might expect, the level of linkages to and from agriculture, as indicated by these intensities, is quite low. Surprisingly, the same is true for "financing, insurance and real estate."

The results for 1998-99, for direct intensities only, indicate relatively little change in magnitudes of agriculture and manufacturing intensities, as well as for their rankings, which capture relative intensities. Services intensities seem to have changed somewhat more from 1993-94 to 1998-99. In particular, "transport, storage and communications," "financing, insurance and real estate," and "personal and social services" all became more services intensive in absolute and relative magnitude. The level of linkages to financial and real estate services remained relatively low, however. Given the expansion of this sub-sector in the 1990 s, and policy statements about creating an international 
financial hub in Mumbai, it would be important to investigate how these linkages have changed since $1998-99 .{ }^{34}$

[Table 5 about here]

One can also calculate backward and forward linkages more formally, using a procedure due to Rasmussen (1956). Backward linkages refer to stimulus from a sector to its inputproviding sectors, while forward linkages capture stimuli in the opposite direction, i.e., downstream in production. Linkage measures are constructed as indices. An index value greater than one indicates a greater than average linkage. ${ }^{35}$ Applying this method to 1998-99 data, ${ }^{36}$ we find that 43 out of the total of 115 activities -6 of 22 agricultural activities, 28 of 80 industrial activities and 9 of 13 services activities - had relative backward index values above one. In fact, 8 of the 9 service activities exceeded the threshold by substantial margins. Therefore, we may conclude that services activities had proportionately the largest inducing effect on the rest in terms of backward linkage. The

\footnotetext{
${ }^{34}$ The issue of linkages is one important aspect of the national economic benefits of pursuing the creation of an international financial services hub. For example, de Jonquieres (2006), in drawing an analogy with national airlines, criticizes the desirability of such a move if it merely serves as a national status symbol. One can conjecture that the linkages from a vibrant, diverse financial sector would be much greater than those from simply operating a national airline, but this needs to be established empirically. Interestingly, Singapore Airlines is a success story partly because it is a national carrier for a regional travel and trade hub - this has an obvious linkage interpretation.

${ }^{35}$ The procedure is as follows. The elements of the Leontief inverse matrix (footnote 33) are adjusted by weighting by the final demand vector. Row sums yield the total forward linkage for each sector or subsector, and the individual row sums relative to their average yield an index or normalized measure of the forward linkage in each sector. The same procedure with column sums yields an index of backward linkages. In each case, indirect as well as direct linkages are accounted for, since the Leontief inverse is used.

${ }^{36}$ Detailed calculations are available from the author. These results are similar to Hansda's figures for 1993-94 data. He finds that 46 of 115 activities - 7 of 22 agricultural activities, 31 of 80 industrial activities and 8 of 13 services activities - had relative backward index values above one. For the forward linkage indices, 15 out of the total of 115 activities -5 out of 22 agricultural activities, 3 out of 80 industrial activities and 7 out of 13 services activities - had high indices greater than one.
} 
results for the forward linkage indices are qualitatively similar, in terms of the relative importance of services: 19 of 115 activities -5 of 22 agricultural activities, 5 of 80 industrial activities and 9 of 13 services activities - had high forward linkage indices. Hansda's aggregated results for 1993-94 (his Table 7) are quite similar to these disaggregated indicators, finding strong backward linkages for "personal, social \& other services" and "transport, storage \& communication" in particular. Forward linkages from services are weaker at this level of aggregation, emphasizing the need to consider as disaggregated a view of the economy as possible.

Two additional pieces of analysis are possible. Hansda (2001) calculates the coefficients of variation for the linkage indices. These coefficients measure the evenness across subsectors of a particular sector's purchases (backward linkages) or sales (forward linkages). The low proportion of services activities with low backward coefficients of variation suggests that the backward linkages from services tend to be concentrated, i.e., their purchases are from a relatively small segment of the economy. Hansda also finds that the forward linkages from services are more evenly spread. Second, given conceptual criticisms of the Rasmussen indices of linkages (e.g., Claus, 2002), he constructs an alternative index of vertical integration, based on the work of Heimler (1991). The results are that 14 out of the 115 activities have index values higher than the average, with 7 of those activities in the services sector, 6 in industry and 1 in agriculture. This supports the view that the services sector has the largest multiplier effect on the rest of the economy. 
One way to interpret the results from the disaggregated input-output analysis is in keeping with the idea that India is a high transaction cost economy (Singh, 2004a). Transportation, trade and communications in India, all sectors which have high impacts on transaction costs, have all been markedly inefficient, held back by inefficiencies in government and by barriers to private participation. The 1980s and 1990s saw this situation begin to change, and a plausible interpretation of Hansda's results is that, through linkages, this change has stimulated the entire economy to some extent. One must bear in mind that this kind of input-output analysis is static, and there is no growth mechanism postulated. Nevertheless, one can argue that, to the extent that growth is driven by innovation, innovations in the services sector are likely to have positive implications for the growth of the rest of the economy. We can explore this hypothesis more explicitly by selectively perturbing input output coefficients, and tracing out the implications.

The theoretical basis for the following exercise is developed in an important paper by Majumdar and Ossella (1999). They show that in an input-output economy, under some further conditions, ${ }^{37}$ the long-run optimal growth factor (i.e., the growth rate plus one) is given by $g=(\delta \lambda)^{1 / \alpha}$, where $\delta$ is the discount factor for the representative consumer, $\alpha$ is the parameter of the constant elasticity one-period utility function (equivalent to the coefficient of relative risk aversion), and $\lambda$ is the inverse of the largest eigenvalue of the input-output matrix. Efficiency gains in sector $j$, such as would result from any kind of

\footnotetext{
${ }^{37}$ In particular, the theory is developed for a closed economy. Mukul Majumdar (personal communication) has pointed out to me that this assumption may have been a tenable approximation for the 1989 data used in their paper, but is less appropriate for the current Indian economy. Nevertheless, we follow the previous methodology, leaving extensions to an open economy to future research.
} 
innovation, are modeled as proportional reductions in all the input requirements of that sector, i.e., the elements of column $j$ of the input-output matrix. The maximal eigenvalue decreases in this case, implying an increase in the optimal growth rate of the economy. Since the other two parameters are unchanged, the ranking of growth rates is equivalent to the ranking of the $\lambda$ 's across all the individual sector perturbations. Hence, the sectors for which exogenous efficiency improvements would have the greatest growth impacts can be clearly identified. These sectors are termed "leading sectors" for the economy. ${ }^{38}$

Majumdar and Ossella using data from 1989, consider both 2 and 5 percent reductions in input requirements, and identify the five leading sectors of the Indian economy for that year, in each case as, in order of growth rate impacts, (1) electricity, gas and water supply, (2) iron and steel, (3) paper and paper products, (4) other chemicals, and (5) other manufacturing. Using $\alpha=0.9,{ }^{39}$ the growth factor for a 5 percent reduction in input requirements in the electricity, gas and water supply sector, relative to the original growth factor, is 1.0081 . To translate this into a growth rate impact, assume that the initial optimal growth rate was 6 percent - the efficiency gain would change the optimal growth rate to 6.9 percent.

We carry out the analysis along the lines of Majumdar and Ossella, using input-output data for 1998-99. We have 115 sectors instead of the 60 sectors used in 1989.

\footnotetext{
${ }^{38}$ Majumdar and Ossella also consider efficiency improvements in combinations of sectors. We leave that to future research as well. Note that the approach is similar in spirit to, and considerably predates the more recent attempt by Hausmann, Rodrik and Velasco (2005) to formalize the relative importance of policy or sectoral constraints. One difference is the focus here on technical efficiency, rather than policy, but the two are naturally connected.

${ }^{39}$ Since one is looking at a ratio of growth factors, the discount factor cancels out, and does not affect the calculations.
} 
Nevertheless, major sectoral classifications are quite similar. We only calculate the impacts of 5 percent efficiency improvements, but consider the 10 leading sectors of the economy. The results are presented in Table 6 . Electricity, gas and water supply remains the most important leading sector, and its growth impact is estimated to be even higher than for the earlier data. Several heavy industry sectors feature in the top 10, paralleling the earlier results. The new feature of our results, however, is the prominence of services. Four services sub-sectors are in the list, and their nature and presence strongly bears out the transaction cost interpretation provided previously in this section.

[Table 6 about here]

As an alternative to using disaggregated input-output data, it is also possible to undertake a dynamic analysis of sectoral growth and linkages within the Indian economy through reduced-form time series modeling. Sastry et al (2002) add a (non-oil) export sector to agriculture, industry and services, and estimate this four equation specification for annual data from 1981-82 to 1999-2000. Linkages from agriculture and industry to services, and agriculture and services to industry are incorporated by including those sectors' outputs as causal variables. On the other hand, agricultural growth is assumed to be determined independently. Their empirical results for the industrial sector come from a straightforward levels regression, and indicate that a 1 per cent rise in services (agriculture) would stimulate industrial output by $0.40(0.25)$ percentage point. 
The services sector presents several additional challenges in terms of assumptions required for empirical analysis. Sastry et al focus only on construction, "trade, hotel and restaurants" and "transport, storage and communication" as endogenous services, subject to linkages, leaving finance, and "community, social and personal services" as exogenous to the system. ${ }^{40}$ The results for the entire sample period, with the equation estimated in growth rate terms, suggest that a percentage point increase in the growth rate of services would lead to a 0.32 percentage point increase in the growth rate of industry. Given the substantial changes in the input-output coefficients over this period, and tests that reject parameter stability, they re-estimate the equation for the 1990s only. The impact of services growth now increases to 0.49 percentage points, and they argue that this is consistent with the 1993-94 input-output tables. In fact, the match is less good than the authors suggest, since the coefficient for agriculture is much higher in the time series specification than in the input-output table. Nevertheless, there is broad consistency from this approach concerning the importance of services.

The input-output linkage analysis is also limited by its focus on what are essentially pecuniary externalities. As noted by Dasgupta and Singh (2005a), the Kaldorian hypothesis of the mechanisms of growth through structural change emphasizes technological externalities or spillovers, rather than pecuniary externalities. In this view, technological externalities are what made manufacturing special in the past, and now explains why ICTs (whether acting through products or services or both) are a special

\footnotetext{
${ }^{40}$ Sastry et al have construction in the services sector, while Hansda includes it in industry. Neither author discusses this choice, and the implications of this different classification are unclear.
} 
driver of growth. ${ }^{41}$ This perspective is also consistent with the analysis of Singh (2003) with respect to the special role of ICTs in the innovation process, as discussed in Section 4. In this context, Singh (2005) also surveys fieldwork and case studies which suggest that there are spillovers from ICTs in rural areas of India. In particular, the introduction of a range of rural ICT-based services not only reduces transaction costs, but also provides spillovers through knowledge acquisition and information access. It has also been argued (e.g., Singh, 2003) that there were substantial spillovers from the IT services industry in India to IT enabled services (ITES), as well as to knowledge intensive sectors in general. These included specific organizational expertise, customer knowledge, and general reputational effects. ${ }^{42}$ In turn, there are linkages and spillovers from ITES to subsectors such as construction and transportation, which not only stimulate demand, but bring in new expertise through creating a different set of requirements and expectations. ${ }^{43}$

\section{International Trade in Services}

Theoretical considerations and empirical evidence both suggest a positive role for trade liberalization in India's growth since the 1980s. Theories of comparative advantage and inter-industry trade (based on product differentiation and economies of scale) do not necessarily distinguish between agriculture, manufacturing and services as likely export

\footnotetext{
${ }^{41}$ An important conceptualization in this context is that ICTs are 'general purpose technologies' (GPTs), distinguished by pervasiveness, technological dynamism and innovational complementarities. See Bresnahan and Trajtenberg (1995), where the term was introduced, and Singh (2003) for a discussion of its applicability to ICTs in India.

${ }^{42}$ Thus, the argument here is that learning is much more general than specialized or context-specific learning: the latter is documented in, e.g., Ethiraj et al (2005). The importance of reputation in the Indian software industry has been established in Banerjee and Duflo (2000).

${ }^{43}$ The involvement of multinationals and the need to serve foreign clients in ITES led to an emphasis on quality of workspaces, and of reliable transportation for employees, affecting both construction and transportation: see, e.g., Khan (2003).
} 
sectors for a developing country, though developing nations are almost invariably those with a relative abundance of unskilled labor. Since much of India's export growth has come in skill-intensive services, ${ }^{44}$ the international aspects of India's "services-led" growth bear examination from empirical and theoretical perspectives. Panagariya (2005) summarizes India's experience with external liberalization, starting in the late 1970s. He documents the acceleration in India's growth rate in the 1980s, and ties this improvement to the external liberalization that took place. Several studies (e.g., Joshi and Little, 1994; Chand and Sen, 2002) formally establish a positive linkage between opening the economy and productivity improvements in manufacturing: this supports the conventional view connecting trade liberalization and development through improvements in manufacturing.

Many developing countries have had to struggle with maintaining balance of payments equilibrium. In India's case, balance of payments crises in the 1970s and before tended to shape a policy of keeping the Indian economy substantially closed to international trade and investment. In this respect, one of the most important aspects of services sector (particularly IT and ITES) growth in India has been its favorable international trade and balance of payments consequences. Hansda (2002) provides some basic documentation of the change in the role of services in India's international trade. For example, India's share in world export of commercial services doubled from $0.6 \%$ in 1990 to $1.2 \%$ in 2000, while its share in global merchandise exports went up only marginally, from $0.5 \%$

\footnotetext{
${ }^{44}$ Rodrik (2006) calculates that India's exports of goods are also more skill-intensive than would be predicted by overall factor endowments. Interestingly, China's exports show the same pattern: Rodrik argues that this indicates the role of policy. This issue is taken up in Section 9.
} 
to $0.7 \%$, in the same period. ${ }^{45}$ Data going back to the 1950 s (Hansda, 2002, Table 10) show that, while India has run a persistent deficit in merchandise trade, there has been a consistent surplus in trade in services. This surplus, only $10 \%$ of the merchandise trade deficit in 1990-91, grew to one-third of that deficit by 2001-02. In aggregate, the ratio of services exports to merchandise exports increased from $25 \%$ to $45 \%$ in that period Much of this increase came in the category of miscellaneous services, which include IT services and ITES such as business process outsourcing (BPO) and call centers. ${ }^{46}$ Hansda also notes the higher positive balance in travel services, and suggests this may be related to a more favourable exchange rate, which was also a consequence of liberalization. Travel connected to IT services and ITES may also have contributed to this increase.

Numerous authors (e.g., Bhagwati, 1985; Gordon and Gupta, 2004; Dasgupta and Singh, 2005a) note the increased ability to deliver services over long distances at a reasonable cost as a result of technological progress in ICTs, which has led to increased worldwide trade in services. Gordon and Gupta estimate that, in India, exports of services (in U.S. dollars) grew by an average of $15 \%$ a year in the 1990 s, compared with $9 \%$ annually in the 1980s. Using the Sastry et al input-output matrix, and making some assumptions about input usage for services exports relative to services overall, they estimate the contribution of exports to annual average services growth is calculated to be about 0.2 percentage points in the $1980 \mathrm{~s}$, and 0.6 percentage points in the 1990s. In their regression analysis, they find that exports of services were highly significant for explaining overall growth of business services, which includes IT services and ITES - seemingly an

\footnotetext{
${ }^{45}$ See also Banga (2005) for additional data on services and overall trade for India.

${ }^{46}$ For a discussion of India's comparative advantage in the IT services sector, see Singh (2004c) and the references therein.
} 
unsurprising result. On the other hand, the growth of other kinds of services did not show much sensitivity to exports.

We have suggested that, in many respects, the recent services growth in India comes from outsourcing by developed country firms that has characteristics of manufacturing, namely scale and routinization. Even in general, trade in services can be analytically treated as similar to trade in goods. This includes trade based on comparative advantage as well as that driven by economies of scale and product differentiation. Bhagwati, Panagariya and Srinivasan (2004) provide some analytical foundations for understanding outsourcing to countries like India in the context of general trade in services. This offshore outsourcing is properly defined, they note, as "offshore trade in arm's length services," distinct from offshore purchases of manufactured components and FDI. ${ }^{47}$ The authors go on to model three kinds of international outsourcing. The result of their analysis in each case is that the welfare impacts of this kind of trade in services are akin to the conventional benefits of trade in goods. ${ }^{48}$ These models and some extensions focus on the impacts of the developed country from which the outsourcing comes. In each case, though, the receiving country should benefit from the new trade, since there is an increased demand for its labor. This kind of theoretical analysis supports the view that new trade in services, such as India is experiencing, provides positive welfare gains. At the same time, these models

\footnotetext{
${ }^{47}$ These distinctions may seem obvious to the economist, but have been blurred in US policy debates, as is discussed in more detail by Bhagwati et al.

${ }^{48}$ The models considered are: 1. A single good, produced with two inputs, labor and capital. Electronically hiring labor from abroad increases welfare, but labor loses while capital benefits. 2. A two-good, threefactor model, with trade in goods. Outsourcing increases national income for a small country, but terms-oftrade effects may cause welfare losses. 3. A three-good two-factor model where a nontraded service becomes tradable. Here owners of both factors of production become better off.
} 
do not incorporate labor with different skill levels, nor can they quantify the benefits of trade.

Putting aside concerns about the magnitude and nature of the growth and employment effects of services trade, one can examine barriers to realizing whatever benefits there are. In addition to IT services and ITES, sub-sectors such as health, education and travel may all have growth and development impacts that are affected by international trade. One possible focus is on the external and demand constraints on India's international trade in services (Banga, 2005). External trade barriers can arise from limits on foreign equity participation, provisions for recognition of qualifications and licensing, immigration and labor market regulations and discriminatory treatment with respect to taxes, subsidies, and other policies. Domestic constraints can result from infrastructure inadequacies, poor quality and standards, lack of clear-cut responsibilities between center and state governments and other policy-related disincentives.

To examine the extent of the constraints to trade in India's services sector Banga classifies services in terms of their external trade barriers i.e., the extent of liberalization, as well as growth rates and the share in exports of services (Table 7, adapted from Banga, 2005, Table 5). The extent of liberalization of services is captured by the FDI cap and restrictions on trade in Mode 4, as classified by the WTO under the General Agreement on Trade in Services (GATS). ${ }^{49}$ The period considered for the extent of liberalization is

\footnotetext{
${ }^{49}$ This classification is based on the constraints on the physical location of producer and consumer in realizing the transaction, The four "modes of supply" are

Mode 1: cross-border supply of service (i.e., not requiring the physical movement of supplier or customer)

Mode 2: Provision implying movement of the consumer to the location of the supplier;
} 
from 1997, since many services were liberalized after that, so the average share in exports is estimated for the period 1997-2003. Banga uses this classification to suggest that services that face high trade barriers (the right hand column) have mostly grown slowly, while others, which have seen moderate liberalization, such as health and education, have had their growth held back by domestic constraints.

[Table 7 about here]

Several sector-specific studies provide more detail on the services sub-sectors in Table 7 (see Banga, 2005 for a review and references). The various external and domestic constraints for these sub-sectors include explicit constraints on FDI and other restrictions, but often just a lack of a coherent set of policies and modern regulatory institutions. Banga offers several policy prescriptions. In particular, health and education are identified as service areas with high growth rates and low export shares, suggesting potential for more trade in these services. Currently, India's trade in health services occurs mainly from mode 4 (movement of health personnel) and mode 2 (inflows of foreign patients for treatment in India from developed and developing countries). The latter is limited by technological and infrastructure constraints (Srinivasan, 2005). Continued telecommunication reforms, such as reduced connectivity costs and lower tariffs will expand the scope for cross-border supply for these services. Even with medical tourism, where doctors do not go abroad, there can be issues of diverting care from the poor. Thus, liberalization and investment in this area would ideally be

Mode 3: services sold in the territory of a Member by (legal) entities that have established a presence there but originate in the territory of another Member;

Mode 4: provision of services requiring the temporary movement of natural persons. 
accompanied by a strengthening of the public health care system. ${ }^{50}$ Regarding trade in education services, Banga emphasizes the need to develop a more robust the system of regulation and accreditation of educational institutions. Srinivasan (2005) similarly notes the possibilities and constraints for mode 2 services trade in education.

Conventional tourism, which can complement health services in particular, as in medical tourism, is particularly constrained by infrastructural shortcomings. Srinivasan (2005) notes that tourism grew by $24 \%$ in 2004 , making India one of the leading tourist destinations in the world. At the same time, the inadequacy of affordable quality hotel rooms, transport and communications still constrains India's ability to attract and absorb tourists. These infrastructure constraints are situated in the services sector, as well as limiting that sector. Even in the case of fast-growing IT and ITES, Srinivasan notes the infrastructure constraints can still hurt growth: "Reliable electric power, efficient and inexpensive telecommunications and access to venture capital are essential infrastructures for the IT sector. Although telecommunications infrastructure has vastly improved, as noted earlier, there are still some unresolved issues relating to the authority of the regulatory agency (Telecommunications Authority of India (TRAI)) vis-à-vis Department of Telecommunication and the state-owned providers. The situation regarding electric power continues to be abysmal." (Srinivasan, 2005, Section 4).

\footnotetext{
${ }^{50}$ An important domestic constraint identified by Banga in the health sector is that it is on the concurrent list of constitutional assignments, so there is a complex set of state and local regulations. Thus, even without a cap on FDI in health services, the share of health services in total trade and FDI is low (only 0.4 percent of total FDI approvals are in health).
} 
One other important potential growth area is financial services (Banga, 2005). Banking and insurance have seen high growth with moderate liberalization of the sector (Table 7). Some of the developments in the financial sector have come from the adoption of information technology, and others from improvements in regulation and legal and institutional frameworks, though much remains to be accomplished in the latter arena. The problem of financially weak and inefficient public sector banks and insurance companies contrasts with modern equity markets that enjoy high trading volumes, and some aggressive and competitive private sector banks such as ICICI Bank.

The input-output analyses of Section 5 do not show much evidence of strong linkages to and from the financial sector, but to the extent that the efficiency of capital allocation is increased through financial development, one can make a case for encouraging the financial services sector, as recent government policy pronouncements have suggested. Since conventional input-output analysis ignores the financial sector, and is static, its enabling role for investment and growth is neglected in that approach. However, several empirical studies for India do support the conclusion that financial sector development would stimulate economic growth (e.g., Bell and Rousseau, 2001; Athukorala and Sen, 2002)..$^{51}$

\footnotetext{
${ }^{51}$ Naastepad (1999) uses a static CGE model with input-output features that tries to capture structural features of the financial system, but her focus is on fiscal and monetary policy channels, rather than impacts of financial sector development.
} 


\section{Employment, Education and Training}

Studies of the development of the services sector in India typically highlight the lack of job growth that has taken place, even as the sector has, to some extent, driven overall GDP growth. To some extent, the problem is a bigger one, since overall job growth has also been anemic. For example, organized sector employment in 1991 was 26.73 million (19.06 public and 7.67 private). By 1997, this had grown a bit, to 28.25 million (19.56 public and 8.69 private). However, in 2003, the numbers had shrunk: 18.58 million public sector employees, 8.42 million private, and 27 million total. Clearly, there are some wellknown institutional and legal constraints in the labor market that inhibit job growth. Aside from these overall constraints, understanding the consequences of India's particular pattern of service sector growth for employment is important. In fact, while some fast-growing segments of IT services have not been subject to restrictive labor laws, they have not altered the overall services employment picture.

There are several accounts of the slow growth of employment in services. Hansda (2002) points out that, while the share of services in employment increased from $20 \%$ in 1970 71 to $23.5 \%$ in $1999-2000$, this was much less than the growth of the services sector's share of GDP, which was from $32.1 \%$ in $1970-71$ to $48.5 \%$ in $2000-01$. Gordon and Gupta (2004) note that, while services rose from 42 percent to 48 percent of GDP during the 1990s, the employment share of services actually declined by about one percentage point during the decade. Of course, the flip side of these observations is that labor productivity in services has grown much faster than in the rest of the economy. Hence, one might re-pose the question of low employment growth in services as one of relatively 
low productivity growth in the rest of the economy. We will return to this issue later in this section. The productivity issue may also be examined to some extent through the input-output coefficients of the Indian economy. Lower coefficients not only imply lower linkages, but also simply lower input intensity. Thus the low linkages of financial services (Table 5) may be partly an indicator of high productivity. The caveat in reaching this as a definite conclusion, of course, is that one does not have a technology benchmark for each sector. Furthermore, splintering complicates any attempt to interpret changes in the coefficients over time.

More disaggregated data on employment in services is presented in Tables 8 and 9. The difference in the pattern of employment generation as well as overall employment growth in the two periods (Table 8) is striking. ${ }^{52}$ Joshi (2004) points out that the slowdown in tertiary (services) sector employment growth in the latter period is chiefly due to the sharp decline in the growth of employment in community, social and personal services. Other, more disaggregated data (Hansda, 2002, Table 4) does suggest that a squeeze on public employment in the 1990s may have been behind the slowdown in employment in community, social and personal services, and hence of services employment. If that was a proper result of controlling wasteful government expenditure, the question that follows is why private sector employment did not compensate more. Possible answers may lie in the quality of the labor force, and the skills it possesses, as well as labor laws. ${ }^{53}$ There may

\footnotetext{
${ }^{52}$ Joshi (2004) characterizes the 1980s as a pre-reform period, but recent work, as summarized in Section 2 above, suggests that this sharp distinction may not be completely justified. Data for 2000-02 (see main text) also suggests caution in associating reform with slow employment growth.

${ }^{53}$ India's labor laws introduce rigidities, and although there is considerable de facto labor market flexibility (Sharma, 2006), it comes about through costly methods of bypassing labor laws and regulations - these costs would discourage employment.
} 
also have been cyclical effects at work, since employment growth picked up subsequently (see below).

\section{[Table 8 about here]}

Total employment impacts for the economy were determined more by changes in agricultural employment growth, than by any slowdown in services employment growth. In the decade 1983-93, half of employment growth came from the primary sector, chiefly agriculture (see Table 9) that. However, in the subsequent six years, primary sector employment actually shrank, while neither industry nor services could pick up the entire slack. Part of this phenomenon can be explained, as suggested by Joshi (2004), by the possibility that the employment absorption capacity of agriculture has reached a saturation limit (see, in particular the discussion in Planning Commission, 2001), while employment growth in the high productivity industrial sector was sluggish in this latter period because of a combination of an industrial sector recession and continued use of relatively capital-intensive-technology.

Joshi goes on to emphasize the services sector as a key area for employment generation however, the figures in Table 9, and the organized sector employment numbers quoted earlier in this section do not give a clear indication that this is happening in any automatic way. ${ }^{54}$ On the other hand, the figures for organized sector employment miss over $90 \%$ of employment in India. In fact, the most recent National Sample Survey Organisation data,

\footnotetext{
${ }^{54}$ In particular, some service sub-sectors appear to be especially capital intensive. Panagariya (2006) calculates that finance, insurance, real estate and business services, which accounted for 13 percent of the GDP in 1999-00, employed only 1.2 percent of the labor force.
} 
released in 2004, estimated that the employment growth rate from 1999-2000 to December 2002 averaged about 2 percent: the same as that in the 1983-94 period, and double the growth rate in the 1994-2000 period. The rise has been more in the urban areas as compared to the rural ones. This translated into about 8 million jobs added per year, with growth coming in chiefly in urban areas and particularly in the small-scale sector. Thus, unorganized sector employment growth outweighed job losses in the corporate sector. $^{55}$

\section{[Table 9 about here]}

Sectoral employment data going back to 1951 (Banga, 2005, Table 3) emphasizes the strikingly poor record of manufacturing employment growth over five decades, though the GDP growth rate was, of course, lower before the 1980s. This would support the view that the real problems in employment generation lie with long-run structural and policy constraints that inhibit employers from hiring, rather than more recent policy changes. Employment elasticities for the 1980s and 1990s (Table 10) may be interpreted similarly. While there is some decrease in employment elasticities in the 1990s, they are low in the

\footnotetext{
${ }^{55}$ Dasgupta and Singh (2005b), based on calculations from NSSO data report that, comparing the two periods 1987-88 to 1993-94 and 1993-94 to 1999-2000, manufacturing employment growth increased from 1.23 percent to 2.58 . However, the organized manufacturing sector had almost no growth in employment during the latter period ( 0.87 percent), while informal manufacturing sector employment (over 80 percent of the total) grew at 2.95 percent. A similar point is made in more detail in Sundaram (2004). He also distinguishes carefully between private and public sector employment, discusses some problems in the statistics, and notes that some of the overall employment slowdown is explained by reductions in female workforce participation associated with poverty reduction. However, Dasgupta and Singh (2005b) report regressions with cross-sectional data for the Indian states, which suggest that formal manufacturing growth is more significant than informal manufacturing for overall growth.
} 
1980s as well, supporting the long-run view of the employment problem. ${ }^{56}$ One is also tempted to conclude from the data that the employment problem is somewhat independent of the fact that employment has lagged GDP growth - the latter, as noted, is an indicator of rising productivity. The cause for concern is that this rising productivity of labor has not translated into a stronger and wider demand for that factor. The answer to that may have something to do with India's pattern of skill-intensive development, itself determined by educational patterns.

[Table 10 about here]

Clearly, the pattern vis-à-vis agricultural employment (Tables 8 and 9) is consistent with a Kaldorian or similar story of development (Dasgupta and Singh, 2005a), with manufacturing somewhat replaced, and definitely supplemented, by services that are organized more on industrial lines. However, as discussed in detail by Kochhar et al (2006), both services and manufacturing in India are apparently more skill intensive than is commensurate with India's level of income and development. This has implications for the pattern of development, in two ways. First, since the scarcity of the requisite skills (e.g., fluency in non-accented English, or a good quality undergraduate engineering degree) acts as an entry barrier to these sectors, rather than development drawing in new job seekers and increasing employment, the earnings of the skilled are being pushed up,

\footnotetext{
56 This discussion is in terms of overall employment elasticities. Note that the sub-sectoral elasticities in Table 9 indicate that the recent decline in employment elasticities has been concentrated in a few sectors, which include large proportions of employment.
} 
often toward developed country levels. ${ }^{57}$ There may be trickle down demand effects, but the consequences for income distribution and social implications may be of concern.

The second implication for development is on the demand side, with the pattern of goods and services being skewed toward the demand pattern of the upper end of the income distribution. In this case, there may not be the kinds of spillovers that would occur in manufacturing, where expertise developed for mass produced goods for the middle classes in rich countries can be transferred to an array of goods that also satisfy wants of the masses in the developing country. The same degree of spillovers may not be available for call centers and BPO operations, which do not necessarily lead to efficiency benefits for the kinds of manufacturing that will employ lower-skilled workers. Of course there are some positive examples: in southern India, in particular, world-class manufacturing firms do seem to be emerging, partly driven by the business environment and culture created by IT and ITES firms.

Some of the above ideas can be incorporated in formal models, which typically assume full employment - the employment issues are then really about the quality of the jobs, and employment in high productivity sectors. New growth theories go beyond considering homogeneous investment as a driver of growth (where diminishing returns will always set in) to emphasize the importance of technical progress, embodied in new varieties of capital and consumption goods, in driving long run or sustained economic growth (e.g., Romer, 1990; Grossman and Helpman, 1991). Those models typically assume homogeneity of consumers, but Sarkar (1998), for example, allows heterogeneity

${ }^{57}$ For example, see the evidence presented in Bosworth, Collins and Virmani (2007). 
of demands, and shows how demand thresholds can matter for growth, ${ }^{58}$ and how a sufficiently large middle class can be crucial in enabling growth. In Sarkar's model, there are three classes of income earners: rich, middle class and poor. Having a large enough middle class is crucial for generating sufficient demand and profits to drive innovation, which in turn creates economic growth. Both the size and the consumption pattern of the middle class matter for growth in this case, and this has obvious connections to Kochhar et al's empirical discussion of skill biases in Indian growth: since these biases will skew consumption demand patterns in a manner that can hurt growth. In fact, in Sarkar's model, transfers from the rich to the middle class or the poor actually decrease long run growth. In his formulation, the only feasible way to increase the growth rate is to promote the poor to the middle class by permanently increasing their productivity - through education, for example.

Thus, both theoretical and empirical analyses of the employment aspects of India's growth experience suggest that constraints on employment can be traced to the labor supply side, in the educational system, as well as to the more obvious labor demand side disincentives that are heavily built into the labor laws (e.g., Besley and Burgess, 2004). The distortion of Indian public spending toward higher education and away from primary education is well known. A significant aspect of the 1990s and the years since has been that a relatively small proportion of Indian higher education graduates, either with professional or technical degrees, or with English communication skills, were able to take advantage of the rapid development of globally-oriented IT services and ITES in this

\footnotetext{
${ }^{58}$ A similar point is made by Murphy, Shleifer and Vishny (1989a) in the context of a static model. This idea is also related in broad terms to the 'big push' view of development advanced in the 1940s by Rosenstein-Rodan - see Murphy, Shleifer and Vishny (1989b) for detailed references and a formal model.
} 
period. Financial and professional services have also started to come under this umbrella, as Indians provide a pool of managerial talent that is small relative to the population, but large in absolute numbers. The constraints on higher education in India create rents for this educated group, as they are now able to participate in an effectively global labor market.

Among the many authors who have analyzed the current state of India's higher education system, Kapur and Mehta (2004) and Kapur and Khilnani (2006) analyze the structural and institutional shortcomings of the organization of the sector. Interestingly, the educational services sector itself does not figure explicitly in all the empirical analyses reviewed in this paper, with the exception of Banga (2005), but it provides the underpinnings for all modern sectors of the economy through its outputs. Kapur and Mehta argue that the dismal overall state of higher education in India is a result of a withering away of public education funding support, because of the unsustainable subsides required by the existing model. At the same time, political interference and capture by vested interests have increased. The result has been a haphazard and uneven privatization, coupled with exit by those who can afford to send their children abroad. Kapur and Khilnani echo these points, and stress the need for removing subsidies to and controls on so-called elite institutions, allowing them to expand efficiently, and transferring resources to areas such as vocational education. They point out that the vocational Industrial Training Institutes (ITIs) receive just 3\% of the higher education budget, and are in even worse shape than the rest of the higher education system. 
The policy measures that would correct the present quality and quantity constraints on the supply of higher education in India are well understood by economists, ${ }^{59}$ but political battles have instead been focused on fighting over the existing rents in the system, through controls on FDI in higher education, and quotas for various societal groups. Instead, free entry into higher education, coupled with a new and more effective system of regulation through certification, disclosure requirements, and media rankings would lead to transparent competition and an expansion of supply precisely where it is needed. Kapur and Mehta fault Indian industry for not being more proactive, since they would benefit, but one can see that in narrow areas such as IT services, firms have been quick to develop training programs and push for their employees to acquire needed qualifications and skills. The problem is with more general skills, which give larger opportunities for benefits to be captured by non-training firms. Even here, in areas such as ITES, firms have tried to develop collective action solutions through industry associations. Wider adoption of such approaches, as well as the alternative of private philanthropy to fund education, will require the government to overhaul its archaic regulatory system and legal frameworks for the provision of education services. Of course, many of these problems are endemic to primary education as well, and similar solutions (though with a stronger public sector involvement because of the greater public good elements of primary education) are desirable. In that sense, what will matter for the sustainability of India's development will be its educational system, and not particular emphasis on

\footnotetext{
${ }^{59}$ In fact, economists seem to be in total agreement here - see also Kochhar et al (2006), and the comments by Banerjee (2006).
} 
manufacturing, services or any sub-sector among them, with the caveat that sub-sectors with greater labor intensities will obviously have more beneficial employment effects. ${ }^{60}$

\section{Social and Environmental Issues}

We have already touched on the concerns about income distribution that arise from India's skill-intensive pattern of growth. Particular kinds of inequality in income may feed into consumption demand in a manner that negatively impacts innovation and growth. To some extent, the skill-intensity observed in India may be exacerbated by the rapid increase in services exports, in sub-sectors where skills that are only available to a relatively small minority (quality engineering and science education, and/or English fluency) are necessary. Increased political battles over entrance to elite educational institutions are an indicator of competition for a service that is increasingly valuable but in very short supply.

The regional dimensions of this political side of the issues arising from India's recent growth are also important, politically as well as for shaping subnational economic policies. Kochhar et al (2006) suggest that the shortage of skilled managerial and supervisory workers, which has already led to their wages rising rapidly, may also give an advantage to those Indian states that are already ahead in the growth race, by magnifying the economic advantages of scale: those states with access to managerial talent can scale up enterprises more easily. The constraints on availability of management

\footnotetext{
${ }^{60}$ Of course, one still needs sensible economic policies that make sure that the demand for labor is not stifled. For decades, India was producing more well-trained graduates than it could productively employ in the private sector.
} 
may also inhibit the growth of labor-intensive manufacture. If the more advanced states attract skilled migrants, who are more mobile than unskilled labor (except, perhaps, at the very bottom rungs such as itinerant construction workers), the poorer states will be further constrained over time. Differences in fertility rates (with economically laggard states like Bihar and Uttar Pradesh seeing greater population increases) will be yet another inequalizing factor. The policy prescriptions offered by Kochhar et al, in addition to reforming and liberalizing higher education, include broader reforms to promote laborintensive activities in agriculture and manufacturing.

The regional picture of growth and structural change is somewhat complicated. Kochhar et al, analyzing the period 1980-2000, find no correlation between growth and the share of manufacturing or of labor-intensive industries, but do find a small positive relationship between growth and the share of services. Using data for the period 1993-94 to 2003-04 (RBI, 2006), we measure structural change for a set of states ${ }^{61}$ in two ways, as percentage changes in sectoral shares, and as percentage point changes in those shares. An index of structural change is constructed by simply adding the absolute values of these sectoral changes (Table 11). While some Tamil Nadu, Haryana and Karnataka are expected examples of states ranking high in structural change, Bihar is surprising in this respect. On the other hand, Gujarat ranks very low in terms of structural change. We also calculated ten-year per capita NSDP growth rates for the states (Table 12) and correlations between growth, initial conditions and structural change. In keeping with the well-documented evidence on income divergence across Indian states, the correlation

\footnotetext{
${ }^{61}$ The states were selected by excluding all special category states except Uttaranchal, which was included as it was formerly part of Uttar Pradesh. The results reported are not sensitive to excluding Uttaranchal, or the small general category state of Goa.
} 
between growth rates and initial-year per capita levels was positive and quite large (0.47).

On the other hand, the correlation between the structural change index and initial year levels was negligible (0.01), and that between growth and structural change was negative $(-0.30) .{ }^{62}$ In addition, we found that the correlation between the change in the share of the service sector and the growth rate was also negative (-0.29), in contrast to Kochhar et al's finding for the longer, earlier time period. In the absence of obvious or expected links between structural change and growth at the level of the state, our conclusion is that further investigation of this issue is required, disaggregating the three sectors further.

Aside from income distribution issues, there have also been concerns about cultural loss associated with the training required by, and lifestyles associated with outsourced services, such as call centers. While surveys suggest that such fears about identity or cultural loss may be somewhat exaggerated, ${ }^{63}$ these factors are real, though nonquantifiable. These fears are also part of broader concerns with growth and modernization (which go back to the industrial revolution), although identity issues such as changing one's name and accent for work, or having to deal with racism from call center customers in developed countries, cut deeper than simply changing patterns of consumption and saving as a consequence of economic growth. In the latter case, one has the extreme perspective embodied in a quote from an Indian middle-class consumer, "I can't resist buying newer models of electronic goodies" (Basu, 2003), but the changes are more far-reaching than just an impulsive desire to consume more, and sooner rather than

\footnotetext{
${ }^{62}$ This last result was qualitatively insensitive to omitting Goa and Gujarat: the sign did not change. It should be noted that the initial year NSDP figure for Gujarat appears to be surprisingly low.

${ }^{63}$ For example, Kamath (2005) uses a 2003 survey made on Indian youth by Taylor Nelson Sofres (TNS), an Indian market research agency, and argues that consumption patterns have changed more than have deeper attitudes towards parents, marriage and religion.
} 
later. They include a greater awareness of, and aspiration for, developed country lifestyles and consumption; greater attention to personal convenience and individuality; greater willingness to experiment and question traditional modes of behavior; and greater optimism about the future. It is not at all clear that these changes are all negative, and recently it has been suggested (in the context of the United States) that innovative attitudes among consumers can actually spur domestic innovation (Bhidé, 2006) in production.

Another aspect of services-led development that goes beyond standard economic growth accounting is that of environmental impacts. In many respects, service sector growth can be more environmentally friendly, to the extent that it avoids heavy industry and its polluting impacts. However, transportation is a service sector that must grow rapidly as well, and which has substantial negative environmental impacts. To some extent, the benefits of services-led industrialization may be that the environmental impacts occur less dramatically in the short run, allowing time for income effects (favoring a clean environment) to work their way through to environmental regulation: in other words, the environmental Kuznets curve may be flatter in this case, though not completely flat. ${ }^{64}$ Services-led industrialization may also avoid problems that come from natural resource export paths of development. In India's case, its forest cover is already heavily depleted, and the problems lie more in domestic consumption of resources than with exports. Any

\footnotetext{
${ }^{64}$ Pandit (2002) does try to incorporate the growth costs of environmental protection into a simple aggregate macroeconometric model for India. Since these costs are borne independently of the pattern of development, there is no implication for the environment of changes in the sectoral distribution of growth. However, one could conceivably calibrate an extended version of Pandit's model to explore differential growth implications of environmental protection, and even allow for feedback effects from such protection. Pandit suggests the latter, but does not implement it in his simulations.
} 
kind of development will increase the domestic demand for resources. This is a function of rapid growth, and the issue of appropriate institutional and regulatory regimes transcends any implications that follow from a specific pattern of development.

\section{Lessons for Development Policy}

In reviewing India's experience with respect to service-sector-led development, we have noted policy implications for international trade, education, and employment generation. In many respects, these are traditional concerns of development policy, and a large theoretical and empirical literature exists on each of these aspects of economic development. While there is some degree of consensus on the importance of education, economic openness, and encouragement of labor intensive activities, debate continues with respect to the degree and specificity of government targeting of particular sectors of a developing economy. The variety of views is considerable, even for a single country like India.

Dasgupta and Singh $(2005 \mathrm{a}, \mathrm{b})$ offer several policy prescriptions based on their examination of the Indian case. These include government support for the informal sector through financial and technical services, a Keynesian attention to maintaining aggregate demand, and a traditional industrial policy approach of identifying dynamic industries that have positive technological and pecuniary externalities for the rest of the economy. ICT-related activities are emphasized in their discussion (see footnote 41), but they also reiterate the importance of encouraging knowledge-intensive industries more generally. 
Dahlman and Utz (2005) develop the latter point in great detail for India, and Dahlman (2006) provides a more general context and framework for this view. Rodrik (2006) makes a more general case for government intervention, based on the view that economic development is fundamentally driven by structural change in the economy, and that this change is "fraught with externalities and spillovers of all kinds." In doing so, he draws on China and India as examples of fast-growing countries with export profiles skewed toward high productivity goods.

However, the nature of government intervention as conceived by Rodrik (2006) is quite circumscribed. His conclusion is worth quoting in detail:

What I understand by "industrial policy" is not an effort by the government to select particular sectors and subsidize them through a range of instruments (directed credit, subsidies, tax incentives, and so on). The critics of industrial policy are correct when they argue that governments do not have adequate knowledge to pick "winners." [I]ndustrial policy is more appropriately conceived as a process whereby the state and the private sector jointly arrive at diagnoses about the sources of blockage in new economic activities and propose solutions to them. Industrial policy requires the government to take an ex-ante stand neither on the activities to be promoted nor on the instruments to be deployed. It simply requires it to build the public-private institutional arrangements whereby information on profitable activities and useful instruments of intervention can be elicited. 
This statement is perhaps the weakest one that can be made with respect to industrial policy. It is consistent with the approach of Hausmann, Rodrik and Velasco (2005) on growth diagnostics. Nevertheless, it appears to leave some room for going beyond the "Washington consensus" (e.g. Ocampo, 2004-5).

Ocampo (2004-5) summarizes several areas where the Washington consensus has been insufficient. What concerns us here is "the role of productive development strategies." In this category, Ocampo emphasizes the need to build institutional capacity, the importance of Schumpeterian innovation (e.g., Amsden, 2001) and structural change, and the standard externality arguments with respect to markets such as those for long-term capital and technology. The Latin American case, in particular, is often used to illustrate the inadequacy of mere liberalization and policy neutrality (e.g., Hausmann, Rodrik and Velasco, 2005; Velasco, 2005; Rodrik, 2006). One might add, however, that all these studies beg the question of political will and feasibility. In particular, the interplay of different interest groups may be the fundamental determinant of which policies are implemented (e.g., Rajan and Zingales, 2006), and of the quality of implementation.

Returning to the Indian case, one can argue that policy reforms that have enabled greater openness, more competition, and better government regulation have not only spurred growth, but have not gone far enough. Impediments to internal trade, labor market rigidities, and barriers to doing business all seem to be factors in keeping economic growth below potential. Making this assertion that reforms have been incomplete does 
not contradict concerns about social and economic inequality. The main issue here is the role of industrial policy, and development policy more generally.

The Indian IT sector, as a major success story, has typically been highlighted as one where government policy made a difference. The key claim here is that the cluster of human and institutional capital in Bangalore, more general government investments in technology education, and government policies that promoted import-substituting industrialization all created the initial conditions that allowed the IT sector to flourish (e.g., Balakrishnan, 2006). On the other hand, there is a case to be made for the "benign neglect" interpretation of the IT sector's success (Kapur, 2002; Murthy, 2004; Singh, 2004c). Government policy certainly did not pick a winner in this case, since there was little or no understanding of, or foresight with respect to, the market for software services. Many of those who were drawn into the sector came with general technical training, rather than skills specifically geared toward the markets that were being served from the 1990s onward.

Nor is it the case that government investment in telecommunications infrastructure in India was based on any analysis or deep understanding of its potential role in facilitating or spurring development and growth. Certainly, government made policy moves from the 1980s onward to improve telecommunications infrastructure and access, but in every case, the impetus came from outside the government (non-resident Indians, in particular), and the slow pace of reform is evidenced in how much India lags behind China in telecommunications access. Thus, the Indian case in the past hardly fits even the weak 
notion of industrial policy as a process that builds "the public-private institutional arrangements whereby information on profitable activities and useful instruments of intervention can be elicited."

Having cautioned against an overly rosy view of past "state-led" development in the Indian case, one can note that this does not preclude such a process from operating beneficially in the future, in the limited manner described by Rodrik. Numerous central and state government actions encouraged and supported IT and ITES once the success of these sectors became evident. A similar dynamic is potentially under way with respect to financial services. ${ }^{65}$ However, the political realities of interest groups are evident in Indian policies that effectively ration access to education at all levels, and various other policies that impose unnecessary costs on the private sector, reduce efficiency and inhibit innovation. We have suggested that broadening economic and institutional reforms, and extending them to government itself, may be more significant in terms of positive impacts than selective interventions in particular sub-sectors, provided that this process tackles emerging inequalities (thus avoiding "Latin Americanization"). In some respects, competition among state governments that has resulted from India's economic reforms (e.g., Singh and Srinivasan, 2005, 2006) may also shape India's political economy in a more favorable direction, ameliorating some of the conflicts highlighted in the abstract by Rajan and Zingales (2006).

\footnotetext{
${ }^{65}$ It is useful to relate these concerns to the discussion of linkages and leading sectors in Section 5. Neither IT nor financial services showed up as leading sectors in that analysis, which identified more traditional services sectors such as trade and transportation, as well as heavy industry sectors as having greater linkages and potential growth impacts. This may reflect the limitations of the closed-economy input-output model, and suggests that further analysis is required to reliably identify where government can make a difference beyond its basic role in providing public goods and infrastructure.
} 


\section{Conclusions}

India's pattern of development, with relatively slow growth of manufacturing, and a more rapid increase in the size of the service sector than would be typical, has received considerable attention. The contribution of this paper has been to provide an integrated appraisal of India's experience and future potential along this growth path. It is straightforward to argue, as several authors have done, that manufacturing, services and agriculture are all important, and broad policy steps to improve growth and employment across the economy are desirable. Specific policy suggestions with respect to improving the tradability and productivity of particular services also emerge from various analyses. Analyses of linkages suggest that certain service sub-sectors of the economy, such as trade, transportation and communications, may be particularly important, but this is also an intuitive conclusion. ${ }^{66}$

Several less obvious implications do emerge from this research. First, some of the dichotomy between services and manufacturing may be overdrawn, as certain kinds of services can be organized in ways that are closer to modern manufacturing. Nevertheless, there are some differences in education requirements, and employment and social impacts, particularly in the skill-intensity required by some of the services that have seen the highest growth in India in the last decade or two. Indeed, the constraints on

\footnotetext{
${ }^{66}$ Here it is worth repeating the observation that financial services may matter beyond their role as measured in the input-output data. Interestingly, if one goes back in time before the industrial revolution, there was a merchant and finance (i.e., services) revolution that got the whole process going, as Sir John Hicks (1969) argued.
} 
appropriate skill acquisition that face the majority of the population in India represent the greatest barrier to any kind of sustained growth, and a major policy challenge in the politically charged arena of education. Tackling the education bottleneck, and adding some labor market reform, may go a long way to allowing Indian industry and its services sector to draw on the large numbers of underemployed, poorly productive people in India's rural heartland.

A few years, ago, the debate on the role of services in India's growth was couched in somewhat simplified terms, as services substituting for manufacturing. Recognizing the blurring conceptual distinction between the modern components of the two sectors helps to refocus the issues on productivity, linkages and distributional concerns, rather than any simple dichotomous choice. China's recent major revision of its GDP figures upwards by one-sixth, with most of that increase coming from a revaluation of services sector activity, is also significant in this context. At a stroke, the estimated contribution of services to China's GDP went up by nine percentage points, crossing 40 percent. This is a much more plausible figure than previous estimates, even though it is still short of the average for countries with similar per capita income levels. The difference between India and China in terms of services' contribution to the economy, at least, has therefore become much less stark. Just as China has focused on manufacturing exports, but seen a stimulation of services activity, in India's case, there may be positive spillovers from services growth to manufacturing, through income and demand, or through organizational learning (just as occurred from IT services to ITES). Ultimately, the bland but appropriate conclusion may be that making the conditions right for enterprise and 
innovation throughout the economy is more important than any targeted intervention toward particular sectors of the economy.

\section{References}

Ahluwalia, Isher J. and C. Rangarajan (1986), 'Agriculture and Industry: A Study of Linkages the Indian Experience', mimeo, World Congress of International Economic Association, December.

Amsden, Alice (2001), The Rise of "The Rest": Challenges to the West from Late Industrializing Countries, New York, Oxford University Press, September.

Athukorala, Prema-Chandra, and Kunal Sen, (2002), Saving, Investment, and Growth in India (New Delhi: Oxford University Press).

Balakrishnan, Pulapre (2006), Benign Neglect or Strategic Intent? Contested Lineage of Indian Software Industry, Economic and Political Weekly, September 9, pp. 3865-3872.

Banga, Rashmi and B.N Goldar (2004), 'Contribution of Services to Output Growth Productivity in Indian Manufacturing: Pre and Post Reform', ICRIER Working Paper No. 139, August.

Banga, Rashmi, (2005), “Critical Issues In India’s Service-Led Growth”, ICRIER Working Paper No. 171 October.

Banerjee, Abhijit V., (2006), The Paradox of Indian Growth: A Comment on Kochhar et al, processed.

Banerjee, Abhijit V. and Esther Duflo, (2000), "Reputation Effects and the Limits of Contracting: A Study of the Indian Software Industry," Quarterly Journal of Economics 115(3), pp. 989-1017.

Basu, I. (2003), India's Growing Urge to Splurge, Asia Times Online, http://www.atimes.com/atimes/South_Asia/EH22Df01.html, accessed January 4, 2005.

Baumol, W. J. (1967), "Macroeconomics of Unbalanced Growth: The Anatomy of Urban Crises." American Economic Review 57, no. 3 (June): 415-26.

Bell, Clive and Peter L. Rousseau, (2001), "Post - Independence India: A Case of Finance - Led Industrialization?” Journal of Development Economics, Vol. 65, 1, pp. 153-75.

Besley, Tim, and Robin Burgess, (2004), "Can Labor Regulation Hinder Economic Performance? Evidence from India", The Quarterly Journal of Economics, Vol. 119, No. 1, pp. 91-134. 
Bhagwati, Jagdish, Arvind Panagariya and T. N. Srinivasan, (2004) "The Muddles over Outsourcing," Journal of Economic Perspectives, Fall

Bhagwati, Jagdish, N. (1984), 'Splintering and Disembodiment of Services and Developing Nations', World Economy, 7(2), June, 133-43.

Bhagwati, Jagdish, N. (1985), 'Why are Services Cheaper in the Poor Countries?', Wealth and Poverty, edited by Gene Grossman Essays in Development Economics Series, vol. 1, Cambridge, MIT Press, England, Blackwell, 82-91.

Bhidé, Amar (2006), 'Venturesome Consumption, Innovation and Globalization,' Paper for a Joint Conference of CESifo and the Center on Capitalism and Society "Perspectives on the Performance of the Continent's Economies," Venice, 21 - 22 July.

Bosworth, Barry, Susan Collins and Arvind Virmani (2007), "Sources of Growth in the Indian Economy," India Policy Forum, forthcoming.

Bresnahan, Timothy, Erik Brynjolfsson, and Loren Hitt (2002), Information Technology, Workplace Organization and the Demand for Skilled Labor: Firm-Level Evidence, Quarterly Journal of Economics, 117(1): 291-303.

Bresnahan, Timothy and Manuel Trajtenberg (1995), General Purpose Technologies: "Engines of Growth", Journal of Econometrics, 65, 83-108.

Chand, Satish and Kunal Sen (2002), Trade Liberalization and Productivity Growth: Evidence from Indian Manufacturing, Review of Development Economics 6, no. 1: 12032.

Ciaschini, M. (1988), (ed.), Input-Output Analysis, London: Chapman and Hall Ltd.

Ciccone, Antonio and Kiminori Matsuyama (1996), Start-up Costs and Pecuniary Externalities as Barriers to Economic Development, Journal of Development Economics, 49 (1), pp. 33-59.

Claus, Iris (2002), 'Inter Industry Linkages in New Zealand', Working Paper 02/09, June, New Zealand Treasury.

Coase, Ronald (1937), The Nature of the Firm, Economica, 4, pp. 386-405.

Dahlman, Carl (2006), Technology, Globalization, and International Competitiveness: Challenges for Developing Countries, UNDESA project paper draft.

Dahlman, Carl and Anuja Utz (2005) India and the Knowledge Economy: Leveraging Strengths and Opportunities, Report No. 31267-IN, World Bank, Washington DC, April.

Dasgupta, Sukti, and Ajit Singh (2005a), Will Services be the New Engine of Economic Growth in India? Centre for Business Research, University of Cambridge Working Paper No. 310, September. 
Dasgupta, Sukti, and Ajit Singh (2005b), Manufacturing, services and premature deindustrialisation in developing countries: a Kaldorian empirical analysis, paper presented at WIDER Jubilee Conference in Helsinki.

De Jonquieres, Guy (2006), Asia seeks fortune in a field of dreams, Financial Times, April 17, www.ft.com (accessed through LexisNexis).

Delaunay, Jean-Claude, and Jean Gadrey, Services in Economic Thought: Three Centuries of Debate, Kluwer Academic Publishers, Boston, 1991

DeLong (2003), J. Bradford DeLong, "India Since Independence: An Analytic Growth Narrative," in In Search of Prosperity: Analytic Narratives on Economic Growth, ed. Dani Rodrik, Princeton, New Jersey: Princeton University Press.

Dossani, Rafiq and Martin Kenney (2004), The Next Wave of Globalization? Exploring the Relocation of Service Provision to India, Working Paper 156, September, The Berkeley Roundtable on the International Economy

Economic Council of Canada (1991), Employment in the Service Sector, Minister of Supply and Services, Canada, Ottawa.

Ethiraj, Sendil K., Prashant Kale, M. S. Krishnan and Jitendra V. Singh, (2005), Where Do Capabilities Come From and How Do They Matter? A Study in the Software Services Industry, Strategic Management Journal, 26: 25-45

Gordon, James, and Poonam Gupta (2004), 'Understanding India's Services Revolution', IMF Working Paper WP/04/171, September.

Griliches, Zvi (1992), (ed.), Output Measurement in the Service Sectors, NBER Studies in Income and Wealth, Vol. 56, University of Chicago Press, Chicago.

Grossman, Gene M. and Elhanan Helpman (1991), Innovation and Growth in the Global Economy, Cambridge, MA: MIT Press.

Gulyani, Sumila (2001), 'Effects of poor transportation on lean production and industrial clustering: Evidence from the Indian auto industry,' World Development, vol. 29, no. 7, July, 1157-1177.

Hansda, Sanjay K. (2001), 'Sustainability of Services-led Growth: An Input-Output Analysis of Indian Economy, RBI Occasional Working Paper, Vol 22, No. 1,2 and 3.

Hansda, Sanjay K. (2002), Services Sector in the Indian Growth Process: Myths \& Realities, The Journal of Income and Wealth, Vol. 24, No. 1 \& 2, January-December 2002.

Hausmann, Ricardo, Dani Rodrik and Andrés Velasco (2005), Growth Diagnostics, working paper, Kennedy School, Harvard University. 
Heimler, A. (1991), 'Linkages and Vertical Integration in the Chinese Economy', The Review of Economics and Statistics, 73, May, 261-267.

Hicks, John R. (1969), A Theory of Economic History, New York, Oxford University Press.

Hill, T. P. (1977), 'On Goods and Services', Review of Income and Wealth, 23 (4), 315 338, December.

Joshi, Seema (2004), 'Tertiary Sector-Driven Growth in India- Impact on Employment and Poverty', Economic and Political Weekly, Special Article, September 11, 2004.

Joshi, Vijay and Ian M. D. Little (1994), India: Macroeconomics and Political Economy: 1961-91, Washington, DC: World Bank.

Kaldor, N. (1966), Causes of the Slow Rate of Economic Growth of the United Kingdom (Cambridge: Cambridge University Press).

Kamath, M.V. (2005), A Changing, Moving, Resurgent India, http://samachar.com/features/130105-features.html, accessed January 21, 2005.

Kapur, Devesh (2002), The Causes and Consequences of India's IT Boom, India Review, $1,1,91-110$.

Kapur, Devesh and Sunil Khilnani (2006), Primary Concerns, Hindustan Times, New Delhi, April $24^{\text {th }}$ and $25^{\text {th }}$.

Kapur, Devesh and Pratap Bhanu Mehta (2004), Indian Higher Education Reform: From Half-Baked Socialism to Half-Baked capitalism, CID working paper No. 108, Harvard University, September.

Kelkar, Vijay (2004), India: On the Growth Turnpike, K.R. Narayanan Oration, Australian National University.

Khan Sabith Ullah (2003) Backward \& Forward Linkages in the ITES/ BPO Industry, Centre for Civil Society, New Delhi.

Kochhar, Kalpana, Utsav Kumar, Raghuram Rajan, Arvind Subramanian, Ioannis Tokatlidis (2006), India's Pattern of Development: What Happened, What Follows?, IMF Working Paper WP/06/22

Kravis, Irving B., Alan Heston, and Robert Summers (1983), 'The Share of Service in Economic Growth', in Global Econometrics: Essays in Honor of Lawrence R. Klein, (ed.) F. Gerard Adams and Bert G. Hickman, Cambridge MA, pp. 188-219.

Kuznets, S. (1959), Six Lectures on Economic Growth, The Free Press of Glencoe, New York. 
Lovelock, Christopher, and Evert Gummesson (2004), Whither Services Marketing? In Search of a New Paradigm and Fresh Perspective, Journal of Service Research, 7 (1), 20 41.

Majumdar, Mukul and Ilaria Ossella (1999), Identifying Leading Sectors that Accelerate the Optimal Growth Rate: A Computational Approach, in Trade, Growth and Development: Essays in Honor of Professor T.N. Srinivasan, Amsterdam: Elsevier Science, pp. 273-290.

Melvin, James R., (1989), Trade in Services: A Theoretical Analysis, Institute for Research on Public Policy, Halifax, 1989.

Melvin, James R.. (1990), Time and Space in Economic Analysis, Canadian Journal of Economics, 23, 725-747, November.

Melvin, James R., (1995), History and Measurement in the Service Sector: A Review, Review of Income and Wealth, Series 41, Number 4, December, 481-494.

Ministry of Finance (2006), Economic Survey of India, 2005-06, http://indiabudget.nic.in/es2005-06/esmain.htm

Mukherji, Joydeep (2006), Economic Growth and India's Future, Occasional Paper 26, Center for Advanced Study of India, University of Pennsylvania

Murphy, K.M., A. Shleifer, and R.W. Vishny, (1989a), Income Distribution, Market Size and Industrialization, Quarterly Journal of Economics, 104: 537-564.

Murphy, K.M., A. Shleifer, and R.W. Vishny, (1989b), Industrialization and the Big Push, Journal of Political Economy, 97(5) October: 1003-1026.

Murthy, N. R. Narayana (2004), The Impact of Economic Reforms on Industry in India: A Case Study of the Software Industry, in in India's Emerging Economy: Performance and Prospects in the 1990's and Beyond, ed. K. Basu, Cambridge, MA: MIT Press, pp. 217-222.

Naastepad, C.W.M., 1999, The Budget Deficit and Macroeconomic Performance: A Real-Financial Computable General Equilibrium Model for India (New Delhi: Oxford University Press).

Ocampo, Jose Antonio (2004-5), Beyond the Washington Consensus: What Do We Mean? Journal of Post Keynesian Economics, Vol. 27, No. 2, Winter, pp. 293-314.

OECD (2004), The Economic Impact of ICT: Measurement, Evidence and Implications, Paris, France: OECD.

Pack, Howard and Larry Westphal (1986), Industrial Strategy and Technological Change: Theory versus Reality, Journal of Development Economics, 22, 87-128. 
Panagariya, Arvind (2005), The Triumph of India's Market Reforms: The Record of the 1980s and 1990s, Policy Analysis, November 7, No. 554.

Panagariya, Arvind (2006), Transforming India, paper presented at the conference "India: An Emerging Giant," October 13-15, 2006, Columbia University.

Pandit, V. N., 2002, "Sustainable Economic Growth for India: An Exercise in Macroeconomic Scenario Building,” CDEDSE Working Paper 100.

Parasuraman, A., Valarie A. Zeithaml, and Leonard L. Berry (1985), 'A Conceptual Model of Service Quality and Its Implications for Future Research,' Journal of Marketing, 49 (Fall), 41-50.

Planning Commission (2001), Report of the Task Force on Employment Opportunities, chaired by Montek S. Ahluwalia, New Delhi, Government of India.

Planning Commission (2002), Report of the Special Group on Targeting Ten Million Employment Opportunities per year over the Tenth Plan Period, chaired by S.P. Gupta, New Delhi, Government of India.

Rajan, Raghuram, and Luigi Zingales (2006), The Persistence of Underdevelopment: Institutions, Human Capital, or Constituencies? Working Paper 12093, National Bureau of Economic Research.

Rao, M. Govinda (2005), Should Indians pay more in taxes?, Business Standard, February 12, available at http://www.businessstandard.com/search/storypage_new.php?leftnm $=1$ mnu5\&leftindx $=5 \& 1$ select $=1$ \&autono= 180612, accessed April 27, $200 \overline{5}$

Rasmussen, P. N. (1956), Studies in Intersectoral Relations, Amsterdam: North Holland.

Reserve Bank of India (2006), Handbook of Statistics for the Indian Economy, www.rbi.org.in.

Rodrik, Dani (2003), "Introduction: What Do We Learn from Country Narratives?" in Dani Rodrik, ed., In Search of Prosperity Analytic Narratives on Economic Growth, Princeton, New Jersey: Princeton University Press.

Rodrik, Dani (2006), Industrial Development: Stylized Facts and Policies, UNDESA project paper draft.

Rodrik, Dani and Arvind Subramanian (2004a), 'From Hindu Growth to Productivity Surge: The Mystery of the Indian Growth Transition', National Bureau of Economic Research Paper, No 10376.

Rodrik, Dani and Arvind Subramanian (2004b), Why India Can Grow at 7 Per Cent a Year or More: Projections and Reflections, Economic and Political Weekly, April 17. 
Romer, Paul (1990), Endogenous Technological Change, Journal of Political Economy, S71-102, October, 98 (5).

Romer, Paul (1994), New Goods, Old Theory, and the Welfare Costs of Trade Restrictions, Journal of Development Economics, 43 (1), pp. 5-38.

Rust, Roland T., and Tuck Siong Chung, 2005, 'Marketing Models of Service and Relationships,' working paper, Robert H. Smith School of Business, University of Maryland, College Park.

Sampson, Gary P., and Richard H. Snape (1985), 'Identifying the Issues in Trade in Services', World Economy. June; 8(2): 171-82.

Sapir, A. \& C. Winter (1994): 'Services Trade', in D. Greenaway and L. Winters (eds.), Surveys in International Trade, Blackwell Economic Theory and the Role of Government in East Asian Industrialization, Princeton University Press, Princeton.

Sarkar, Abhirup (1998), Endogenous Growth and the Size of the Market, Keio Economic Studies, 35 (1), pp. 29-44.

D V S Sastry, D.V.S., Balwant Singh, Kaushik Bhattacharya, and N. K. Unnikrishnan (2003), Sectoral Linkages and Growth Prospects: Reflections on the Indian Economy, Economic and Political Weekly, June 14, pp. 2392-2397.

Sharma, Alakh N. (2006), Flexibility, Employment and Labour Market Reforms in India, Economic and Political Weekly, May 27, 2078-85.

Shome, Parthasarathi (2006), At the Threshold of 10 Per Cent Economic Growth?, Economic and Political Weekly, March 18.

Singh, Nirvikar (2002), Information Technology as an Engine of Broad-Based Growth in India, in The Knowledge Economy in India, ed. Parthasarathi Banerjee and Frank-Jürgen Richter, London: Palgrave/Macmillan, pp. 34-57.

Singh, Nirvikar (2003), India's Information Technology Sector: What Contribution to Broader Economic Development? , OECD Development Centre Technical Papers, no. 207, March.

Singh, Nirvikar (2004a), Transaction Costs, Information Technology and Development, UCSC Economics Department Working Paper, October.

Singh, Nirvikar (2004b), Information Technology and Rural Development in India, in Integrating the Rural Poor into Markets, Bibek Debroy and Amir Ullah Khan, eds., New Delhi: Academic Foundation, pp. 221-246.

Singh, Nirvikar (2004c), Information Technology and India's Economic Development, in India's Emerging Economy: Performance and Prospects in the 1990's and Beyond, ed. K. Basu, MIT Press, pp. 223-261 
Singh, Nirvikar (2005), ICTs and Rural Development in India, University of California, Santa Cruz, USA, Draft, in progress, December.

Singh, Nirvikar and T.N. Srinivasan (2005), Indian Federalism, Economic Reform and Globalization, in Jessica Wallack and T.N. Srinivasan, eds., Federalism and Economic Reform: International Perspectives: Cambridge University Press, pp. 301-363.

Singh, Nirvikar and T.N. Srinivasan (2006), Federalism and Economic Development in India: An Assessment", October, UCSC Economics Department Working Paper No. 625.

Srinivasan, T.N. (2003), Indian Economy: Current Problems and Future Prospects, Working Paper No. 173, Stanford Center for International Development, July.

Srinivasan, T. N. (2005), Information Technology Enabled Services and India's Growth Prospects, Forthcoming in Lael Brainard and Susan M. Collins (editors): Offshoring White-Collar Work - The Issues and Implications, The Brookings Trade Forum.

Sundaram, K. (2004), Growth of Work Opportunities In India: 1983 - 1999-2000, Centre for Development Economics, Delhi School of Economics, India

Triplett Jack E., and Barry P. Bosworth, Productivity in the U.S. Services Sector: New Sources of Economic Growth, Brookings Institution Press, 2004.

Vargo, Stephen L., and Robert F. Lusch (2004), Evolving to a New Dominant Logic for Marketing, Journal of Marketing, 68 (January), 1-17.

Velasco, Andres (2005), Why Doesn't Latin America Grow More, and What Can We Do About It?, working paper, Kennedy School, Harvard, October.

Wallack, Jessica (2003), Structural Breaks in Indian Macroeconomic Data, Economic and Political Weekly, October $11^{\text {th }}, 4312-4315$.

Weitzman, Martin (1998), Recombinant Growth, Quarterly Journal of Economics, 113, 2, 331-360.

Williamson, Oliver E. (1975), Markets and Hierarchies: Analysis and Antitrust Implications, New York: The Free Press.

Williamson, Oliver E. (1981), The Economics of Organization: The Transaction Cost Approach, American Journal of Sociology, 87 (3), pp. 548-577. 


\section{Table 1: Services Sub-sectors for India}

\begin{tabular}{|c|c|}
\hline Sector & Activities Included \\
\hline $\begin{array}{l}\text { Trade, hotels and restaurant } \\
\text { Trade (distribution services) }\end{array}$ & $\begin{array}{l}\text { Wholesale and retail trade in commodities both } \\
\text { produced at home (including exports) and imported, } \\
\text { purchase and selling agents, brokers and auctioneers }\end{array}$ \\
\hline Hotels \& Restaurants & $\begin{array}{l}\text { Services rendered by hotels and other lodging places, } \\
\text { restaurants, cafes and other eating and drinking places }\end{array}$ \\
\hline \multicolumn{2}{|l|}{$\begin{array}{l}\text { Transport, storage and } \\
\text { communication } \\
\text { Railways }\end{array}$} \\
\hline Transport by other means & $\begin{array}{l}\text { Road, water, air transport, services incidental to } \\
\text { transport }\end{array}$ \\
\hline \multicolumn{2}{|r|}{$T_{T}$} \\
\hline Communication & $\begin{array}{l}\text { Postal, money orders, telegrams, telephones, overseas } \\
\text { communication services, miscellaneous }\end{array}$ \\
\hline \multicolumn{2}{|l|}{$\begin{array}{l}\text { Financing, insurance, real } \\
\text { estate and business services }\end{array}$} \\
\hline Banking & $\begin{array}{l}\text { Banks, banking department of RBI, post office saving } \\
\text { bank, non-bank financial institution, cooperative credit } \\
\text { societies, employees provident fund }\end{array}$ \\
\hline Insurance & Life, postal life, non-life \\
\hline \multicolumn{2}{|l|}{ Dwellings, real estate } \\
\hline \multicolumn{2}{|l|}{ Business services } \\
\hline \multicolumn{2}{|l|}{ Legal services } \\
\hline \multicolumn{2}{|l|}{$\begin{array}{l}\text { Community, social and } \\
\text { personal services }\end{array}$} \\
\hline \multicolumn{2}{|l|}{ Public administration, defense } \\
\hline Personal services & $\begin{array}{l}\text { Domestic, laundry, barber, beauty shops, tailoring, } \\
\text { others }\end{array}$ \\
\hline Community services & $\begin{array}{l}\text { Education, research, scientific, medical, health, } \\
\text { religious and other community }\end{array}$ \\
\hline Other services & $\begin{array}{l}\text { Recreation, entertainment, radio, TV broadcast, } \\
\text { sanitary services }\end{array}$ \\
\hline
\end{tabular}

Source: Banga (2005) 
Table 2: Structural Breaks in India's Growth Rates

\begin{tabular}{lcc}
\hline \multicolumn{1}{c}{ Series } & Break Year 1 & Break Year 2 \\
\hline GDP & $1980^{* *}$ & \\
GNP & $1987^{* *}$ & \\
Trade, transport, storage, and communication & $1992^{* *}$ & $1980^{* * *}$ \\
$\begin{array}{l}\text { Finance, insurance, real estate, and business } \\
\text { services }\end{array}$ & $1974^{* *}$ & \\
$\begin{array}{l}\text { Agriculture, forestry and logging, fishing, } \\
\text { mining and quarrying }\end{array}$ & 1979 \\
$\begin{array}{l}\text { Manufacturing, construction, electricity, gas } \\
\text { and water supply }\end{array}$ & 1964 \\
$\begin{array}{l}\text { Registered manufacturing } \\
\text { Public administration, defense and other }\end{array}$ & 1964 \\
services & 1993 \\
\hline
\end{tabular}

Source: Wallack (2003)

Notes: $* *$ indicates sup-F statistic significant at $5 \%$ level, $* * *$ at $1 \%$ level 
Table 3: Sectoral Production Linkages

\begin{tabular}{lccc}
\hline & Agriculture & Industry & Services \\
\hline 1968-69 & & & \\
$\quad$ Agriculture & 0.182 & 0.127 & 0.017 \\
$\quad$ Industry & 0.043 & 0.333 & 0.132 \\
$\quad$ Services & 0.016 & 0.135 & 0.096 \\
1979-80 & & & \\
$\quad$ Agriculture & 0.160 & 0.130 & 0.039 \\
$\quad$ Industry & 0.068 & 0.345 & 0.105 \\
$\quad$ Services & 0.020 & 0.149 & 0.096 \\
1989-90 & & & \\
$\quad$ Agriculture & 0.166 & 0.042 & 0.035 \\
$\quad$ Industry & 0.144 & 0.373 & 0.172 \\
$\quad$ Services & 0.047 & 0.188 & 0.185 \\
1993-94 & & & \\
$\quad$ Agriculture & 0.145 & 0.035 & 0.034 \\
Industry & 0.140 & 0.365 & 0.150 \\
$\quad$ Services & 0.048 & 0.213 & 0.195 \\
1998-99 & & & \\
Agriculture & 0.117 & 0.081 & 0.019 \\
$\quad$ Industry & 0.075 & 0.397 & 0.145 \\
$\quad$ Services & 0.050 & 0.173 & 0.144 \\
\hline
\end{tabular}

Source: pre-1998-99 figures, Sastry et al (2002); 1998-99 figures, author's calculations 
Table 4: Distribution of Activities with Above Average Sectoral Intensity

\begin{tabular}{|c|c|c|c|c|c|c|c|c|c|}
\hline \multirow{3}{*}{$\begin{array}{l}\text { Activity } \\
\text { Categories } \\
\text { (number) }\end{array}$} & \multicolumn{3}{|c|}{ Agriculture Intensive } & \multicolumn{3}{|c|}{ Industry Intensive } & \multicolumn{3}{|c|}{ Services Intensive } \\
\hline & \multicolumn{2}{|c|}{$\begin{array}{c}\text { Direct } \\
\text { intensity }\end{array}$} & \multirow{2}{*}{$\begin{array}{c}\text { Direct \& } \\
\text { indirect } \\
\text { intensity } \\
1993-94\end{array}$} & \multicolumn{2}{|c|}{$\begin{array}{c}\text { Direct } \\
\text { intensity }\end{array}$} & \multirow{2}{*}{$\begin{array}{c}\text { Direct \& } \\
\text { indirect } \\
\text { intensity } \\
1993-94\end{array}$} & \multicolumn{2}{|c|}{$\begin{array}{c}\text { Direct } \\
\text { intensity }\end{array}$} & \multirow{2}{*}{$\begin{array}{r}\text { Direct \& } \\
\text { indirect } \\
\text { intensity } \\
1993-94\end{array}$} \\
\hline & $\begin{array}{c}1993- \\
94\end{array}$ & $\begin{array}{l}1998- \\
99\end{array}$ & & $\begin{array}{c}1993- \\
94\end{array}$ & $\begin{array}{l}1998- \\
99\end{array}$ & & $\begin{array}{c}1993- \\
94\end{array}$ & $\begin{array}{l}1998- \\
99\end{array}$ & \\
\hline $\begin{array}{l}\text { Agricultural } \\
\text { activities (22) }\end{array}$ & 15 & 14 & 15 & 0 & 0 & 0 & 1 & 1 & 1 \\
\hline $\begin{array}{l}\text { Industrial } \\
\text { activities (80) }\end{array}$ & 18 & 19 & 22 & 57 & 61 & 55 & 56 & 57 & 59 \\
\hline $\begin{array}{l}\text { Service } \\
\text { activities (13) }\end{array}$ & 1 & 1 & 1 & 3 & 3 & 3 & 6 & 7 & 2 \\
\hline $\begin{array}{l}\text { Total activities } \\
\text { (115) }\end{array}$ & 34 & 34 & 38 & 60 & 64 & 58 & 63 & 65 & 62 \\
\hline $\begin{array}{l}\text { Average } \\
\text { intensity }\end{array}$ & 7 & 6 & 12 & 29 & 24 & 59 & 15 & 14 & 30 \\
\hline
\end{tabular}

Source: 1993-94 figures, Hansda (2001, Table 5); 1998-99 figures, from author's calculations 
Table 5: Sectoral Intensity - Aggregate Categories

\begin{tabular}{|c|c|c|c|c|c|c|c|c|c|}
\hline \multirow{3}{*}{ Sector } & \multicolumn{3}{|c|}{ Agriculture } & \multicolumn{3}{|c|}{ Industry } & \multicolumn{3}{|c|}{ Services } \\
\hline & \multicolumn{2}{|c|}{$\underset{\text { (Rank) }}{\mathbf{G}}$} & \multirow{2}{*}{$\begin{array}{c}\text { G* }^{*} \\
\text { (Rank) } \\
93-94\end{array}$} & \multicolumn{2}{|c|}{$\underset{\text { (Rank) }}{\mathbf{G}}$} & \multirow{2}{*}{$\begin{array}{c}\text { G* } \\
\text { (Rank) } \\
\text { 93-94 }\end{array}$} & \multicolumn{2}{|c|}{$\begin{array}{c}G \\
\text { (Rank) }\end{array}$} & \multirow{2}{*}{$\begin{array}{c}\text { G* } \\
\text { (Rank) } \\
\text { 93-94 }\end{array}$} \\
\hline & $93-94$ & 98-99 & & 93-94 & 98-99 & & 93-94 & 98-99 & \\
\hline Agriculture & $\begin{array}{l}0.131 \\
(2)\end{array}$ & $\begin{array}{l}0.093 \\
(3)\end{array}$ & $\begin{array}{c}0.172 \\
(3)\end{array}$ & $\begin{array}{c}0.092 \\
(7)\end{array}$ & $\begin{array}{r}0.091 \\
(7)\end{array}$ & $\begin{array}{c}0.211 \\
(8)\end{array}$ & $\begin{array}{c}0.057 \\
(10)\end{array}$ & $\begin{array}{l}0.051 \\
(9)\end{array}$ & $\begin{array}{c}0.122 \\
(8)\end{array}$ \\
\hline Allied activities & $\begin{array}{l}0.179 \\
(1)\end{array}$ & $\begin{array}{l}0.173 \\
(1)\end{array}$ & $\begin{array}{c}0.220 \\
(1)\end{array}$ & $\begin{array}{c}0.039 \\
(10)\end{array}$ & $\begin{array}{r}0.038 \\
(10)\end{array}$ & $\begin{array}{l}0.127 \\
(9)\end{array}$ & $\begin{array}{c}0.068 \\
(8)\end{array}$ & $\begin{array}{c}0.049 \\
(10)\end{array}$ & $\begin{array}{c}0.121 \\
(9)\end{array}$ \\
\hline Mining \& quarrying & $\begin{array}{l}0.000 \\
(9)\end{array}$ & $\begin{array}{l}0.000 \\
(9)\end{array}$ & $\begin{array}{c}0.028 \\
(9)\end{array}$ & $\begin{array}{c}0.190 \\
(5)\end{array}$ & $\begin{array}{r}0.143 \\
(6)\end{array}$ & $\begin{array}{c}0.358 \\
(5)\end{array}$ & $\begin{array}{l}0.070 \\
(7)\end{array}$ & $\begin{array}{c}0.059 \\
(8)\end{array}$ & $\begin{array}{c}0.152 \\
(7)\end{array}$ \\
\hline Manufacturing & $\begin{array}{l}0.091 \\
(3)\end{array}$ & $\begin{array}{l}0.110 \\
(2)\end{array}$ & $\begin{array}{l}0.179 \\
(2)\end{array}$ & $\begin{array}{l}0.420 \\
(2)\end{array}$ & $\begin{array}{r}0.417 \\
(2)\end{array}$ & $\begin{array}{l}0.811 \\
(1)\end{array}$ & $\begin{array}{l}0.185 \\
(2)\end{array}$ & $\begin{array}{l}0.179 \\
(2)\end{array}$ & $\begin{array}{c}0.385 \\
(1)\end{array}$ \\
\hline Construction & $\begin{array}{l}0.024 \\
(5)\end{array}$ & $\begin{array}{c}0.021 \\
(5)\end{array}$ & $\begin{array}{l}0.095 \\
(4)\end{array}$ & $\begin{array}{l}0.362 \\
(3)\end{array}$ & $\begin{array}{r}0.340 \\
(3)\end{array}$ & $\begin{array}{l}0.706 \\
(3)\end{array}$ & $\begin{array}{c}0.202 \\
(1)\end{array}$ & $\begin{array}{l}0.171 \\
(4)\end{array}$ & $\begin{array}{c}0.381 \\
(2)\end{array}$ \\
\hline $\begin{array}{l}\text { Electricity, gas \& water } \\
\text { supply }\end{array}$ & $\begin{array}{c}0.004 \\
(8)\end{array}$ & $\begin{array}{c}0.003 \\
(8)\end{array}$ & $\begin{array}{c}0.038 \\
(8)\end{array}$ & $\begin{array}{c}0.453 \\
(1)\end{array}$ & $\begin{array}{r}0.440 \\
(1)\end{array}$ & $\begin{array}{l}0.800 \\
(2)\end{array}$ & $\begin{array}{l}0.166 \\
(4)\end{array}$ & $\begin{array}{l}0.176 \\
(3)\end{array}$ & $\begin{array}{l}0.330 \\
(3)\end{array}$ \\
\hline $\begin{array}{l}\text { Transport, storage \& } \\
\text { communication }\end{array}$ & $\begin{array}{l}0.023 \\
(6)\end{array}$ & $\begin{array}{l}0.005 \\
(7)\end{array}$ & $\begin{array}{c}0.074 \\
(5)\end{array}$ & $\begin{array}{l}0.282 \\
(4)\end{array}$ & $\begin{array}{r}0.276 \\
(4)\end{array}$ & $\begin{array}{c}0.560 \\
(4)\end{array}$ & $\begin{array}{l}0.175 \\
(3)\end{array}$ & $\begin{array}{l}0.191 \\
(1)\end{array}$ & $\begin{array}{c}0.317 \\
(4)\end{array}$ \\
\hline $\begin{array}{l}\text { Trade, hotels \& } \\
\text { restaurants }\end{array}$ & $\begin{array}{c}0.034 \\
(4)\end{array}$ & $\begin{array}{l}0.048 \\
(4)\end{array}$ & $\begin{array}{c}0.060 \\
(6)\end{array}$ & $\begin{array}{c}0.091 \\
(8)\end{array}$ & $\begin{array}{r}0.083 \\
(8)\end{array}$ & $\begin{array}{l}0.214 \\
(7)\end{array}$ & $\begin{array}{l}0.160 \\
(5)\end{array}$ & $\begin{array}{c}0.131 \\
(6)\end{array}$ & $\begin{array}{c}0.227 \\
(5)\end{array}$ \\
\hline $\begin{array}{l}\text { Financing, insurance \& } \\
\text { real estate }\end{array}$ & $\begin{array}{c}0.000 \\
(10)\end{array}$ & $\begin{array}{c}0.000 \\
(10)\end{array}$ & $\begin{array}{c}0.006 \\
(10)\end{array}$ & $\begin{array}{l}0.044 \\
(9)\end{array}$ & $\begin{array}{r}0.056 \\
(9)\end{array}$ & $\begin{array}{c}0.089 \\
(10)\end{array}$ & $\begin{array}{c}0.061 \\
(9)\end{array}$ & $\begin{array}{c}0.105 \\
(7)\end{array}$ & $\begin{array}{c}0.087 \\
(10)\end{array}$ \\
\hline $\begin{array}{l}\text { Personal, social \& other } \\
\text { services }\end{array}$ & $\begin{array}{c}0.016 \\
(7)\end{array}$ & $\begin{array}{c}0.013 \\
(6)\end{array}$ & $\begin{array}{c}0.048 \\
(7)\end{array}$ & $\begin{array}{c}0.152 \\
(6)\end{array}$ & $\begin{array}{r}0.157 \\
(5)\end{array}$ & $\begin{array}{c}0.301 \\
(6)\end{array}$ & $\begin{array}{c}0.090 \\
(6)\end{array}$ & $\begin{array}{l}0.144 \\
(5)\end{array}$ & $\begin{array}{c}0.167 \\
(6)\end{array}$ \\
\hline Average Intensity & 0.050 & 0.064 & 0.092 & 0.212 & 0.241 & 0.418 & 0.123 & 0.139 & 0.229 \\
\hline
\end{tabular}

Source: 1993-94 figures, Hansda (2001), Table 6; 1998-99 figures, from author's calculations. Definitions: G: Direct sectoral intensity; G*: Direct and indirect sectoral intensity. 
Table 6: Leading Sectors, 1998-99

\begin{tabular}{lcc}
\hline & $\begin{array}{c}\text { Relative } \\
\text { growth factor }\end{array}$ & $\begin{array}{c}\text { Growth rate } \\
\text { (base 6 percent) }\end{array}$ \\
\hline Electricity, gas \& water supply & 1.0108 & 7.14 \\
Iron, steel and ferro-alloys & 1.0049 & 6.52 \\
Non-ferrous basic metals & 1.0037 & 6.40 \\
Other services & 1.0031 & 6.32 \\
Other transport services & 1.0028 & 6.29 \\
Railway transport services & 1.0020 & 6.21 \\
Coal and lignite & 1.0018 & 6.19 \\
Trade & 1.0016 & 6.17 \\
Miscellaneous manufacturing & 1.0016 & 6.17 \\
Inorganic heavy chemicals & 1.0013 & 6.14 \\
\hline
\end{tabular}

Source: author's calculations. 
Table 7: Categorization of Services by Extent of Trade Liberalization and Growth

\begin{tabular}{llll}
\hline & \multicolumn{1}{c}{$\begin{array}{c}\text { Substantially } \\
\text { Liberalized }\end{array}$} & \multicolumn{1}{c}{$\begin{array}{c}\text { Moderately } \\
\text { Liberalized }\end{array}$} & \multicolumn{1}{c}{$\begin{array}{c}\text { Less than Moderately } \\
\text { Liberalized / Restricted }\end{array}$} \\
\hline $\begin{array}{l}\text { High growth } \\
(\mathbf{1 0 \%} \text { and above) }\end{array}$ & $\begin{array}{l}\text { Software Services H } \\
\text { Telecommunication M }\end{array}$ & $\begin{array}{l}\text { Bnsurance M } \\
\text { Travel H } \\
\text { Health L } \\
\text { Education L }\end{array}$ & \\
$\begin{array}{l}\text { Moderate Growth } \\
(\mathbf{5 - 9 \% )}\end{array}$ & & & Legal L \\
$\begin{array}{l}\text { Low growth } \\
(\mathbf{0 - 5 \% )}\end{array}$ & Road Transport L & Construction L & Professional Services, e.g., \\
\hline
\end{tabular}

Source: Banga (2005), Table 5

Notes: H: High share in exports of services ( $10 \%$ and above)

M: Moderate share in exports of services (5-9\%)

L: Low share in exports of services (less than 5\%) 
Table 8: Growth of Employment by Sectors

\begin{tabular}{|c|c|c|c|c|c|}
\hline \multirow[t]{2}{*}{ Industry } & \multicolumn{3}{|c|}{ Employed Workers, Millions (\%) } & \multicolumn{2}{|c|}{ Annual Growth Rates, \% } \\
\hline & 1983 & 1993-94 & 1999-2000 & 1983-94 & 1994-2000 \\
\hline Primary & $\begin{array}{c}208.99 \\
(69.0)\end{array}$ & $\begin{array}{c}245.16 \\
(65.5)\end{array}$ & $\begin{array}{c}239.83 \\
(60.4)\end{array}$ & 1.60 & -0.34 \\
\hline 1. Agriculture & & & & 1.51 & -0.34 \\
\hline 2. Mining and quarrying & & & & 4.16 & -2.85 \\
\hline Secondary & $\begin{array}{l}41.66 \\
(13.8)\end{array}$ & $\begin{array}{l}55.53 \\
(14.8)\end{array}$ & $\begin{array}{l}66.91 \\
(16.8)\end{array}$ & 2.91 & 3.14 \\
\hline 3. Manufacturing & & & & 2.14 & 2.05 \\
\hline $\begin{array}{l}\text { 4. Electricity, gas and } \\
\text { water supply }\end{array}$ & & & & 4.50 & -0.88 \\
\hline 5. Construction & & & & 5.32 & 7.09 \\
\hline Tertiary & $\begin{array}{l}52.11 \\
(17.2)\end{array}$ & $\begin{array}{l}73.76 \\
(19.7)\end{array}$ & $\begin{array}{l}90.26 \\
(22.7)\end{array}$ & 3.53 & 2.42 \\
\hline 6. Trade & & & & 3.57 & 5.04 \\
\hline $\begin{array}{l}\text { 7. Transport, storage and } \\
\text { communication }\end{array}$ & & & & 3.24 & 6.04 \\
\hline 8. Financial services & & & & 7.18 & 6.20 \\
\hline $\begin{array}{l}\text { 9. Community, social and } \\
\text { personal services }\end{array}$ & & & & 2.90 & 0.55 \\
\hline Total employment & $\begin{array}{c}302.76 \\
(100)\end{array}$ & $\begin{array}{c}374.45 \\
(100)\end{array}$ & $\begin{array}{c}397.00 \\
(100)\end{array}$ & 2.04 & 0.98 \\
\hline
\end{tabular}

Source: adapted from Joshi (2004) 
Table 9: Shares of Different Sectors in Increase of Employment (Million)

\begin{tabular}{lrrrrrrr}
\hline \multicolumn{1}{c}{ Sectors } & 1983 & $1993-94$ & $\begin{array}{c}\text { Increase } \\
\text { during } \\
1983-93\end{array}$ & $\begin{array}{c}\text { Share in } \\
\text { Increase, } \\
\%\end{array}$ & $\begin{array}{c}1999- \\
2000\end{array}$ & $\begin{array}{c}\text { Increase } \\
\text { during } \\
1994-2000\end{array}$ & $\begin{array}{c}\text { Share in } \\
\text { Increase, } \\
\%\end{array}$ \\
\hline Primary & 208.99 & 245.16 & 36.17 & 50.5 & 239.83 & -5.33 & -23.6 \\
Secondary & 41.66 & 55.53 & 13.87 & 19.3 & 66.91 & 11.38 & 50.4 \\
Tertiary & 52.11 & 73.76 & 21.65 & 30.2 & 90.26 & 16.50 & 73.2 \\
\hline Total & 302.76 & 374.45 & 71.69 & 100.00 & 397.00 & 22.55 & 100.00 \\
\hline
\end{tabular}

Source: adapted from Joshi (2004) 
Table 10: Sectoral Employment Elasticities

\begin{tabular}{lccc}
\hline Sectors & $\begin{array}{c}\mathbf{1 9 8 3} \\
\text { to } \\
\mathbf{1 9 8 7 - 8 8}\end{array}$ & $\begin{array}{c}\mathbf{1 9 8 3} \\
\text { to } \\
\mathbf{1 9 9 3 - 9 4}\end{array}$ & $\begin{array}{c}\mathbf{1 9 9 3 - 9 4} \\
\text { to } \\
\mathbf{1 9 9 9 - 2 0 0 0}\end{array}$ \\
\hline Agriculture & 0.87 & 0.70 & 0.01 \\
Mining and quarrying & 1.25 & 0.59 & -0.41 \\
Manufacturing & 0.59 & 0.38 & 0.33 \\
Electricity, gas and water supply & 0.30 & 0.63 & -0.52 \\
Construction & 2.81 & 0.86 & 0.82 \\
Trade, hotels and restaurants & 0.87 & 0.68 & 0.62 \\
Transport, storage and communication & 0.47 & 0.55 & 0.63 \\
Financing, insurance, real estate and & 0.49 & 0.45 & 0.64 \\
business services & & & -0.25 \\
Community, social and personal & 0.52 & 0.68 & 0.16 \\
services & 0.68 & 0.52 & \\
\hline ALL & & &
\end{tabular}

Source: Planning Commission (2002) 
Table 11: Structural Change in Selected Indian States

\begin{tabular}{|c|c|c|c|c|c|c|}
\hline & & Agriculture & Industry & Services & $\begin{array}{c}\text { Sum of } \\
\text { absolute } \\
\text { values }\end{array}$ & $\begin{array}{c}\text { Structural } \\
\text { change rank }\end{array}$ \\
\hline \multirow[t]{4}{*}{ Andhra Pradesh } & 1993-94 share & 35.9 & 15.5 & 48.5 & 100.0 & \\
\hline & 2003-04 share & 28.3 & 15.3 & 56.4 & 100.0 & \\
\hline & Percent change & -21.3 & -1.6 & 16.3 & 39.2 & 14 \\
\hline & Percentage point change & -7.7 & -0.3 & 7.9 & 15.8 & 13 \\
\hline \multirow[t]{4}{*}{ Bihar } & 1993-94 share & 51.4 & 5.2 & 43.5 & 100.0 & \\
\hline & 2003-04 share & 38.0 & 2.8 & 59.1 & 100.0 & \\
\hline & Percent change & -26.0 & -45.3 & 36.1 & 107.4 & 2 \\
\hline & Percentage point change & -13.4 & -2.3 & 15.7 & 31.4 & 4 \\
\hline \multirow[t]{4}{*}{ Chhattisgarh } & 1993-94 share & 34.3 & 30.0 & 35.7 & 100.0 & \\
\hline & 2003-04 share & 23.8 & 30.1 & 46.1 & 100.0 & \\
\hline & Percent change & -30.5 & 0.3 & 29.1 & 59.8 & 10 \\
\hline & Percentage point change & -10.5 & 0.1 & 10.4 & 20.9 & 9 \\
\hline \multirow[t]{4}{*}{ Goa } & 1993-94 share & 15.9 & 32.4 & 51.7 & 100.0 & \\
\hline & 2003-04 share & 7.8 & 32.5 & 59.7 & 100.0 & \\
\hline & Percent change & -51.1 & 0.5 & 15.4 & 66.9 & 9 \\
\hline & Percentage point change & -8.1 & 0.1 & 8.0 & 16.2 & 12 \\
\hline \multirow[t]{4}{*}{ Gujarat } & 1993-94 share & 24.3 & 30.9 & 44.9 & 100.0 & \\
\hline & 2003-04 share & 21.3 & 30.5 & 48.2 & 100.0 & \\
\hline & Percent change & -12.1 & -1.4 & 7.5 & 21.0 & 18 \\
\hline & Percentage point change & -2.9 & -0.4 & 3.4 & 6.7 & 18 \\
\hline \multirow[t]{4}{*}{ Haryana } & 1993-94 share & 42.6 & 18.0 & 39.4 & 100.0 & \\
\hline & 2003-04 share & 25.8 & 24.0 & 50.3 & 100.0 & \\
\hline & Percent change & -39.6 & 33.4 & 27.6 & 100.5 & 3 \\
\hline & Percentage point change & -16.9 & 6.0 & 10.9 & 33.7 & 3 \\
\hline \multirow[t]{4}{*}{ Jharkhand } & 1993-94 share & 26.4 & 38.8 & 34.9 & 100.0 & \\
\hline & 2003-04 share & 24.2 & 35.9 & 39.9 & 100.0 & \\
\hline & Percent change & -8.2 & -7.5 & 14.5 & 30.1 & 17 \\
\hline & Percentage point change & -2.2 & -2.9 & 5.1 & 10.1 & 17 \\
\hline \multirow[t]{4}{*}{ Karnataka } & 1993-94 share & 37.5 & 19.2 & 43.3 & 100.0 & \\
\hline & 2003-04 share & 19.3 & 18.9 & 61.8 & 100.0 & \\
\hline & Percent change & -48.5 & -1.7 & 42.8 & 93.0 & 5 \\
\hline & Percentage point change & -18.2 & -0.3 & 18.5 & 37.0 & 2 \\
\hline \multirow[t]{4}{*}{ Kerala } & 1993-94 share & 32.0 & 12.3 & 55.7 & 100.0 & \\
\hline & 2003-04 share & 18.6 & 10.9 & 70.4 & 100.0 & \\
\hline & Percent change & -41.8 & -10.7 & 26.4 & 78.9 & 7 \\
\hline & Percentage point change & -13.4 & -1.3 & 14.7 & 29.4 & 6 \\
\hline \multirow[t]{4}{*}{ Madhya Pradesh } & 1993-94 share & 42.9 & 16.0 & 41.1 & 100.0 & \\
\hline & 2003-04 share & 33.7 & 16.4 & 49.9 & 100.0 & \\
\hline & Percent change & -21.5 & 2.5 & 21.5 & 45.6 & 12 \\
\hline & Percentage point change & -9.2 & 0.4 & 8.8 & 18.5 & 11 \\
\hline \multirow[t]{4}{*}{ Maharashtra } & 1993-94 share & 20.7 & 26.4 & 52.9 & 100.0 & \\
\hline & 2003-04 share & 12.7 & 19.8 & 67.4 & 100.0 & \\
\hline & Percent change & -38.5 & -25.0 & 27.6 & 91.1 & 6 \\
\hline & Percentage point change & -8.0 & -6.6 & 14.6 & 29.2 & 7 \\
\hline
\end{tabular}


Table 11 (contd.): Structural Change in Selected Indian States

\begin{tabular}{|c|c|c|c|c|c|c|}
\hline & & Agriculture & Industry & Services & $\begin{array}{c}\text { Sum of } \\
\text { absolute } \\
\text { values }\end{array}$ & $\begin{array}{l}\text { Structural } \\
\text { change rank }\end{array}$ \\
\hline \multirow[t]{4}{*}{ Orissa } & 1993-94 share & 44.3 & 13.8 & 41.9 & 100.0 & \\
\hline & 2003-04 share & 36.5 & 13.9 & 49.6 & 100.0 & \\
\hline & Percent change & -17.5 & 0.8 & 18.2 & 36.5 & 15 \\
\hline & Percentage point change & -7.8 & 0.1 & 7.6 & 15.5 & 14 \\
\hline \multirow[t]{4}{*}{ Punjab } & 1993-94 share & 48.2 & 15.3 & 36.4 & 100.0 & \\
\hline & 2003-04 share & 38.3 & 15.6 & 46.1 & 100.0 & \\
\hline & Percent change & -20.7 & 1.9 & 26.6 & 49.1 & 11 \\
\hline & Percentage point change & -10.0 & 0.3 & 9.7 & 19.9 & 10 \\
\hline \multirow[t]{4}{*}{ Rajasthan } & 1993-94 share & 35.2 & 15.5 & 49.3 & 100.0 & \\
\hline & 2003-04 share & 29.1 & 16.3 & 54.5 & 100.0 & \\
\hline & Percent change & -17.2 & 5.5 & 10.5 & 33.2 & 16 \\
\hline & Percentage point change & -6.0 & 0.8 & 5.2 & 12.1 & 16 \\
\hline \multirow[t]{4}{*}{ Tamil Nadu } & 1993-94 share & 25.6 & 27.2 & 47.1 & 100.0 & \\
\hline & 2003-04 share & 12.1 & 18.2 & 69.7 & 100.0 & \\
\hline & Percent change & -52.8 & -33.2 & 47.9 & 133.9 & 1 \\
\hline & Percentage point change & -13.5 & -9.0 & 22.6 & 45.2 & 1 \\
\hline \multirow[t]{4}{*}{ Uttar Pradesh } & 1993-94 share & 41.1 & 15.3 & 43.6 & 100.0 & \\
\hline & 2003-04 share & 36.3 & 13.1 & 50.6 & 100.0 & \\
\hline & Percent change & -11.7 & -14.0 & 16.0 & 41.7 & 13 \\
\hline & Percentage point change & -4.8 & -2.1 & 7.0 & 13.9 & 15 \\
\hline \multirow[t]{4}{*}{ Uttaranchal } & 1993-94 share & 39.8 & 17.0 & 43.2 & 100.0 & \\
\hline & 2003-04 share & 31.1 & 10.3 & 58.5 & 100.0 & \\
\hline & Percent change & -21.7 & -39.2 & 35.4 & 96.3 & 4 \\
\hline & Percentage point change & -8.6 & -6.7 & 15.3 & 30.6 & 5 \\
\hline \multirow[t]{4}{*}{ West Bengal } & 1993-94 share & 34.7 & 17.9 & 47.4 & 100.0 & \\
\hline & 2003-04 share & 27.1 & 13.3 & 59.6 & 100.0 & \\
\hline & Percent change & -21.8 & -25.8 & 25.7 & 73.4 & 8 \\
\hline & Percentage point change & -7.6 & -4.6 & 12.2 & 24.4 & 8 \\
\hline
\end{tabular}

Source: author's calculations from RBI (2006) 
Table 12: Per Capita NSDP Changes in Selected Indian States

\begin{tabular}{lrrrrr}
\hline State & $\mathbf{1 9 9 3 - 9 4}$ & $\mathbf{2 0 0 3 - 0 4}$ & $\begin{array}{c}\text { Growth } \\
\text { (percent) }\end{array}$ & $\begin{array}{c}\text { Growth } \\
\text { rank }\end{array}$ & $\begin{array}{c}\text { Structural } \\
\text { change } \\
\text { index }\end{array}$ \\
\hline Andhra Pradesh & & & & & 1516 \\
Bihar & 3037 & 11756 & 58.52 & 5 & 15.8 \\
Jharkhand & 5897 & 7732 & 31.12 & 13 & 20.9 \\
Goa & 16558 & 30506 & 84.24 & 1 & 16.2 \\
Gujarat & 9796 & 16780 & 71.29 & 3 & 6.7 \\
Haryana & 11079 & 15752 & 42.18 & 9 & 33.7 \\
Karnataka & 7838 & 13141 & 67.66 & 4 & 10.1 \\
Kerala & 7983 & 12328 & 54.43 & 7 & 37 \\
Madhya Pradesh & 6584 & 8284 & 25.82 & 16 & 29.4 \\
Chhattisgarh & 6539 & 8383 & 28.20 & 14 & 18.5 \\
Maharashtra & 12183 & 16479 & 35.26 & 11 & 29.2 \\
Orissa & 4896 & 6487 & 32.50 & 12 & 15.5 \\
Punjab & 12710 & 16119 & 26.82 & 15 & 19.9 \\
Rajasthan & 6182 & 9685 & 56.66 & 6 & 12.1 \\
Tamil Nadu & 8955 & 12976 & 44.90 & 8 & 45.2 \\
Uttar Pradesh & 5066 & 5975 & 17.94 & 17 & 13.9 \\
Uttaranchal & 6896 & 9471 & 37.34 & 10 & 30.6 \\
West Bengal & 6756 & 11612 & 71.88 & 2 & 24.4 \\
\hline
\end{tabular}

Source: author's calculations from RBI (2006) 